This is the peer reviewed version of the following article: Golston, C. and Kehrein, W. (2015) A Prosodic Theory of Vocalic Contrasts, in The Segment in Phonetics and Phonology (eds E. Raimy and C. E. Cairns), John Wiley \& Sons, Ltd, Chichester, UK. doi: 10.1002/9781118555491.ch4, which has been published in final form at http://dx.doi.org/10.1002/9781118555491.ch4. This article may be used for non-commercial purposes in accordance with Wiley Terms and Conditions for Self-Archiving. 


\title{
A prosodic theory of vocalic contrasts*
}

\author{
Chris Golston and Wolfgang Kehrein \\ California State University Fresno and University of Groningen/University of Amsterdam
}

Phonetic transcription allows us to put in square brackets many things that languages do not actually make use of, such as palatalized velar glides [ $\left.\mathrm{u}^{\mathrm{j}}\right]$ or velarized palatal glides $\left[\mathrm{j}^{\mathrm{\gamma}}\right]$. It also allows us to posit unattested contrasts like pre- vs. post-palatalized nasals $\left[{ }^{\mathrm{j}} \mathrm{n} \sim \mathrm{n}^{\mathrm{j}}\right]$ and to entertain what seem to be purely orthographic contrasts like [pja $\left.\sim \mathrm{p}^{\mathrm{j} a}\right]$. We argue here that natural language does not use such refined distinctions and offer a more restrictive theory of vocalic features that treats them as properties of syllable margins (onsets and codas) rather than properties of individual consonants. Following Ladefoged \& Maddieson (1996, 2), our study focuses on the elements "that are known to distinguish lexical items within a language", i.e., on minimal-pair contrasts involving labialization, palatalization, and velarization within single morphemes. ${ }^{1}$ The facts we present here suggest that natural languages allow at most a single unordered set of vocalic features per syllable margin, whatever the number of segments in that domain. For this reason, we propose that

(1) An onset or coda has a single unordered set of vocalic features.

The idea that vocalic features may characterize prosodic levels above the segment is not new of course (Harris 1944; Firth 1948, 1957; Goldsmith 1990). What is novel here is our claim that secondary vocalic features only characterize prosodic levels above the segment, that no consonant licenses vocalic features on its own. A number of predictions follow from this claim that do not follow from segmental or subsegmental accounts of vocalic licensing. Specifically, we expect to find:

\footnotetext{
* We thank Gulmira Moldalieva and Natalie Operstein for their help. Neither of them is responsible for infelicities or inaccuracies, which are our own.

1 We exclude pharyngeal glides and pharyngealized consonants from the present discussion, but assume that they too are governed by onset and coda.
}

To appear. Charles Cairns and Eric Raimy (eds.), The Segment in Phonology and Phonetics. Wiley-Blackwell. 
(2) No conflicting vocalic contrasts within a syllable margin

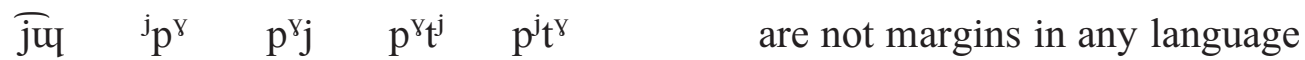

(3) No pre/post contrasts within a syllable margin

${ }^{\mathrm{j}} \mathrm{p} \sim \mathrm{p}^{\mathrm{j}} \quad \mathrm{jp} \sim \mathrm{pj} \quad{ }^{\mathrm{j}} \mathrm{pt} \sim \mathrm{p}^{\mathrm{j} t} \sim \mathrm{p}^{\mathrm{j}} \sim \mathrm{p}^{\mathrm{j} \mathrm{t}^{\mathrm{j}}} \quad$ do not contrast in margins in any language

${ }^{\mathrm{x}} \mathrm{p} \sim \mathrm{p}^{\mathrm{\gamma}} \quad$ uр $\sim$ pщ $\quad{ }^{\mathrm{x}} \mathrm{pt} \sim \mathrm{p}^{\mathrm{\gamma} t} \sim \mathrm{pt}^{\mathrm{\gamma}} \sim \mathrm{p}^{\mathrm{\gamma}} \mathrm{t}^{\mathrm{\gamma}} \quad$ do not contrast in margins in any language

(4) No segment/cluster contrasts within a syllable margin

$$
\begin{array}{lll}
\mathrm{p}^{\mathrm{j}} \sim \mathrm{pj} & \mathrm{pt}^{\mathrm{j}} \sim \mathrm{ptj} & \text { do not contrast in margins in any language } \\
\mathrm{p}^{\mathrm{X}} \sim \mathrm{pu} & \mathrm{pt}^{\mathrm{X}} \sim \mathrm{ptu} & \text { do not contrast in margins in any language }
\end{array}
$$

We give a few examples of onsets with secondary vocalic features below to illustrate how our prosodic treatment of vocalic features models the restrictions in (2)-(4). We abbreviate featural representations here to focus on our claim that each onset (or coda) has a single set of laryngeal features (SL = supra-laryngeal):

(5) Prosodic licensing: vocalic features are licensed by syllable margins (onset and coda)

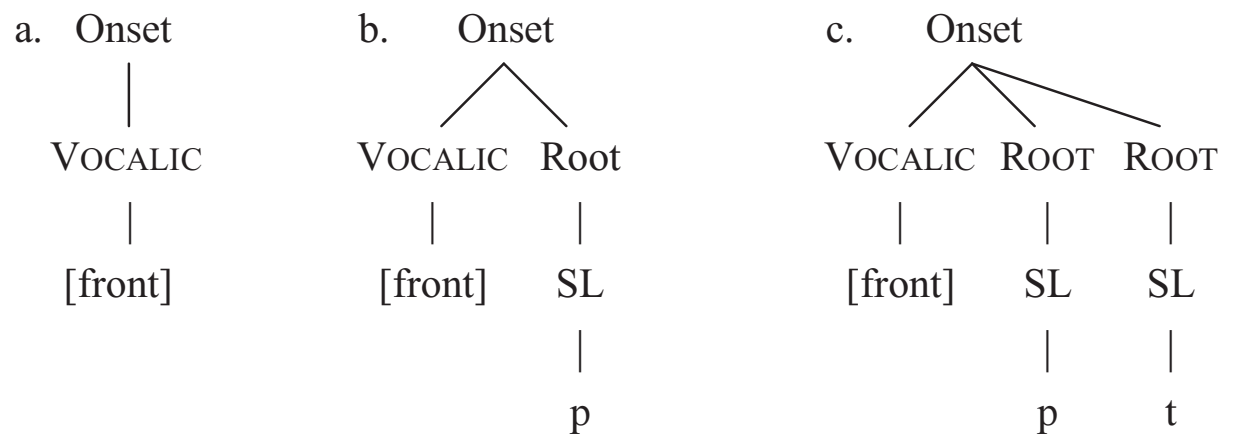

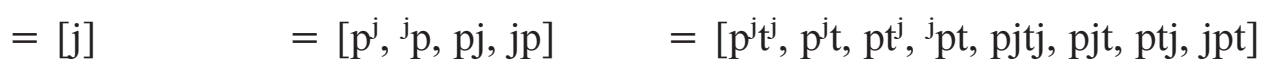

The tree in (5a) shows a palatal glide, a simple onset with the vocalic feature [front $]^{2}$ and no consonantal specifications, like the first sound in yellow. If a simple onset has a single vocalic node, we rule out a velarized $\mathrm{j}\left[\mathrm{j}^{\mathrm{y}}\right]$, a palatalized $\mathrm{u}_{[}\left[\mathrm{u}^{\mathrm{j}}\right]$, and a palato-velar glide [jü] using feature co-occurrence restrictions against [front] and [back] familiar from previous work (e.g., Hall 1997).

The tree in (5b) shows [front] linked to an onset with a labial stop; we intend no temporal ordering between the vocalic node and the root node that is its sister. According to our proposal in (1), this phonological representation covers both palatalized stops $\left[\mathrm{p}^{\mathrm{j}},{ }^{\mathrm{j}} \mathrm{p}\right]$ and clusters made up of a stop plus a palatal glide [pj, jp], since palatalization $\left(^{j}\right)$ and palatal glides $(\mathrm{j})$ are indistinguishable under our account, both consisting of a [front] specification directly linked to the onset. This models universals (3) and (4) above: no language contrasts

2 We take all features to be privative and we follow the earlier standard assumption of all vowels being dorsal for reasons that will become clear below (see Halle et al. 2000, for discussion). 
pre- and post-palatalized sounds ( ${ }^{\mathrm{j}} \mathrm{p}$ vs. $\mathrm{p}^{\mathrm{j}}$, jp vs. pj) or vocalized segments and glideconsonant clusters ( ${ }^{\mathrm{j}} \mathrm{p}$ vs. jp, $\mathrm{p}^{\mathrm{j}}$ vs. $\mathrm{pj}$ ), we propose, because there is no distinct way of representing them phonologically.

(5c) shows palatalization of a complex onset [pt]: it differs from (5a) and (5b) by addition of consonantal articulations, but it does not differ with respect to vocalic specifications on our model. Given at most one set of vocalic features per onset and coda (1), there is no way to multiply vocalic features in an onset or coda by increasing the number of segments. Thus (5c) represents not only [ $\left.\mathrm{p}^{\mathrm{j}} \mathrm{t}^{\mathrm{j}}\right]$ but also [ $\left.\mathrm{pt}^{\mathrm{j}}\right]$, [pjtj], [ptj], and a

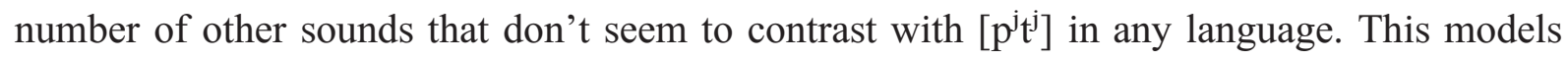
(2), (3), and (4) for complex constituents: no language allows for contrastive ordering or conflicting vocalic features in complex onsets or codas. This rules out tautosyllabic clusters like [ju] and [uj] as well without further stipulation.

We may contrast this prosodic approach to a more traditional approach in which each segment bears its own set of vocalic features (e.g., Clements \& Hume 1995 or the theory implicit in the international phonetic alphabet; see van de Weijer 2011 for discussion):

(6) Segmental licensing: vocalic features are licensed by individual segments

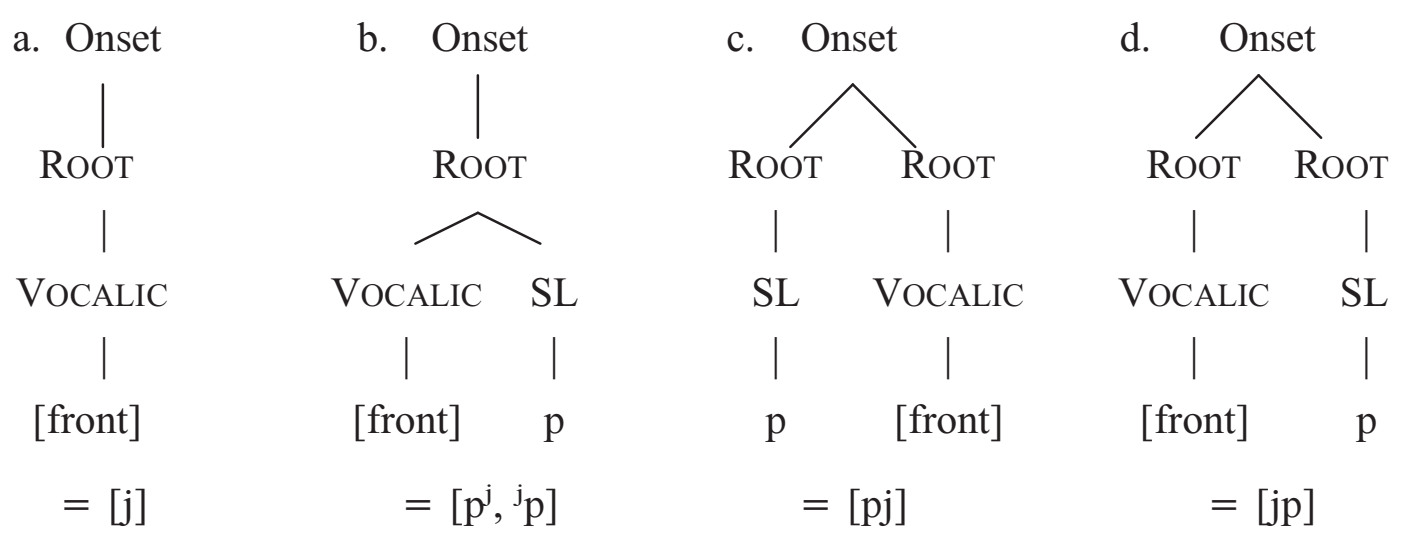

Segmental and prosodic licensing accounts are pretty much identical for pure vocalic sounds $(5 \mathrm{a}=6 \mathrm{a})$ and both predict that $\left[\mathrm{p}^{\mathrm{j}}\right]$ and $\left[{ }^{\mathrm{j}} \mathrm{p}\right]$ don't contrast $(6 \mathrm{~b})$ by assuming that the vocalic features within a segment or syllable margin cannot be ordered contrastively. Both types of model also rule out a velarized palatal glide $\left[\mathrm{j}^{\mathrm{\gamma}}\right]$ and a palatalized velar glide $\left[\mathrm{u}^{\mathrm{j}}\right]$, by means of feature co-occurrence restrictions within a segment or syllable margin. But segmental models make markedly different predictions for glide-consonant clusters (6c, 6d). Segmental licensing of vocalic features is compatible with a three-way phonological contrast among such that [ $\mathrm{p}^{\mathrm{j} a t}$, pjat, jpat] might constitute a minimal triple in some language, where $\mathrm{p}^{\mathrm{j}}, \mathrm{pj}$ and jp are all part of the syllable onset. The prosodic approach we propose here is not compatible with such a contrast, in line with the crosslinguistic facts we will present here. 
Segmental licensing makes markedly different predictions for complex constituents of the type in $(5 \mathrm{c})$ as well. If every sound can host its own vocalic specification, we expect to find syllables like $\left[p^{j} t^{\gamma} a\right]$ or $\left[p^{\gamma} t^{j} a\right]$, where two consonants in the same syllable margin have conflicting vocalic features $\left({ }^{\mathrm{j}}\right.$ requiring a front tongue position and ${ }^{\mathrm{y}}$ a back):

(7) Segmental licensing: vocalic features are licensed by individual segments

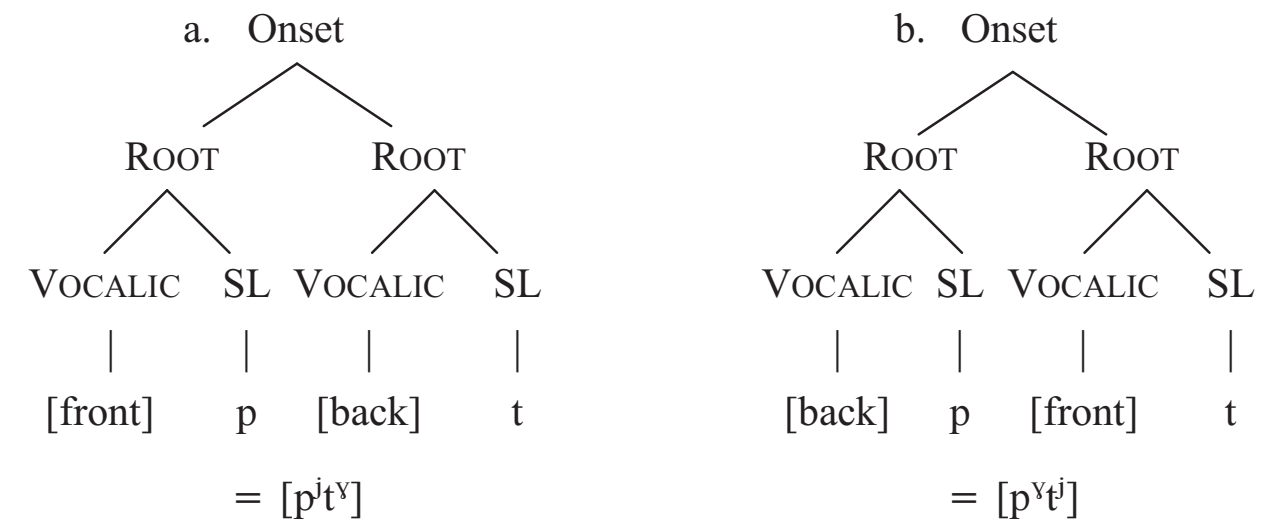

Such onsets do not occur in the languages of the world as far as we can tell, and thus constitute an overprediction on the part of segmental licensing models. Segmental licensing also predicts three-way contrasts like the following, where $\left[p^{j} t^{j} a \sim p^{j} t a \sim p t^{j} a\right]$ are a minimal triple:

(8) Segmental licensing: vocalic features are licensed by individual segments

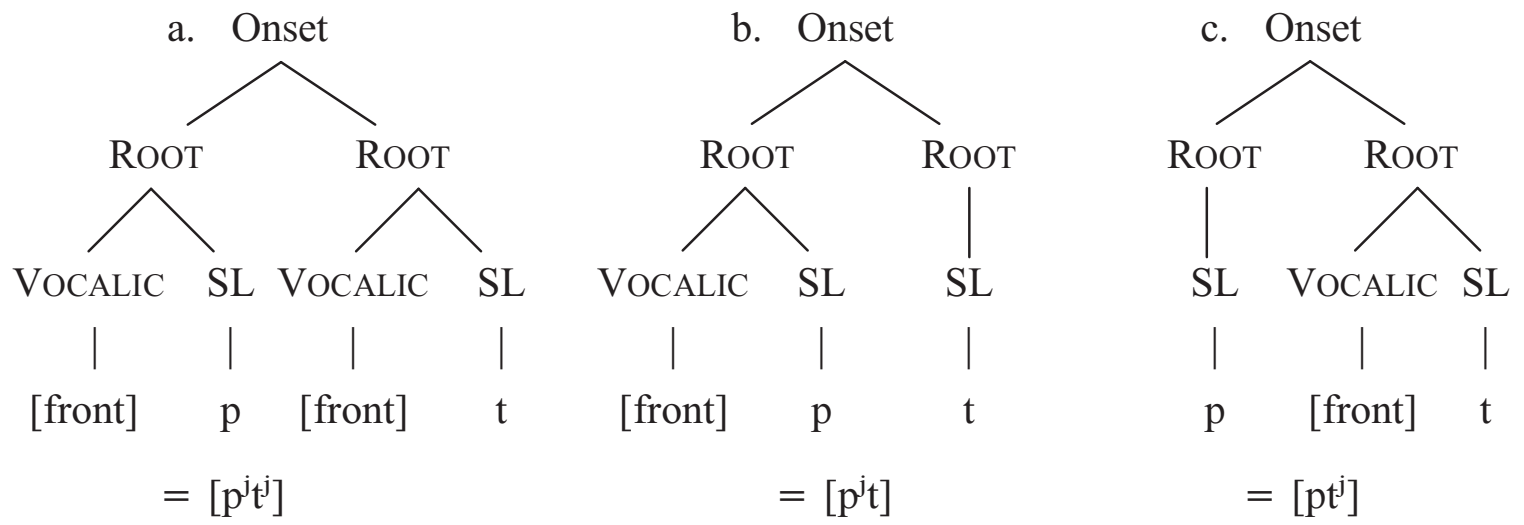

Again, our prosodic approach is not compatible with such types of contrast; if no language contrasts such sounds with one another, as seems to be the case, our prosodic approach comes closer to a segmental approach in modeling what is out there.

We note here at the outset that our results are not meant to argue for a particular set of vocalic features. We use [front, back, round] instead of, e.g., [coronal, dorsal, labial] 
(Clements \& Hume 1995), but we expect our claims to hold either way. ${ }^{3}$ In this paper, we focus on what licenses features rather than the set of features so licensed.

Our findings parallel those of our earlier work on laryngeals (Kehrein \& Golston 2004) where we propose that:

(9) An onset, nucleus, or coda has a single unordered set of laryngeal features.

That claim was based on the following observations about laryngeal contrasts in the languages of the world, parallel to (2-4) above:

(10) No conflicting laryngeal contrasts within a margin or nucleus

\begin{tabular}{|c|c|c|c|}
\hline ' $\mathrm{p}^{\prime} \mathrm{h}^{2}$ & hp? h? & $\mathrm{p}^{\mathrm{h}} \mathrm{t}^{\prime} \mathrm{p}^{\prime} \mathrm{t}^{\mathrm{h}}$ & are not margins in any language \\
\hline $\bar{a} \overline{a a}$ & ha? Pah & ai ai ai & are not nuclei in any language \\
\hline
\end{tabular}

(11) No pre/post contrasts within a margin or nucleus

\begin{tabular}{|c|c|c|c|}
\hline${ }^{h} p \sim p^{h}$ & $\mathrm{hp} \sim \mathrm{ph}$ & $\mathrm{p}^{\mathrm{h}} \mathrm{t} \sim \mathrm{pt}^{\mathrm{h}}$ & do not contrast in margins in any language \\
\hline${ }^{2} p \sim$ p' & ?p $\sim \mathrm{p} ?$ & $p^{\prime} t \sim p t^{\prime}$ & do not contrast in margins in any language \\
\hline$\widehat{a ̣ a} \sim \widetilde{a a ̣}$ & ha $\sim$ ha & ại $\sim$ ạ & do not contrast in nuclei in any language \\
\hline$\widetilde{\mathrm{aa}} \sim \widetilde{\mathrm{aa}}$ & $\mathrm{Pa} \sim \mathrm{a} ?$ & $\underset{\sim}{\mathrm{ai}} \sim$ ai & do not contrast in nuclei in any language \\
\hline
\end{tabular}

(12) No segment/cluster contrasts within a margin or nucleus

$$
\begin{array}{ll}
\mathrm{p}^{\mathrm{h}} \sim \mathrm{ph} & \mathrm{pt}^{\mathrm{h}} \sim \mathrm{pth} \\
\mathrm{p}^{\prime} \sim \mathrm{p} ? & \mathrm{pt} \sim \mathrm{pt} ? \\
\mathrm{a} \sim \mathrm{ah} & \mathrm{a} \mathrm{i} \sim \mathrm{ahi} \\
\underset{\sim}{\mathrm{a} \sim \mathrm{a} ?} & \underset{\sim}{\mathrm{ai}} \sim \mathrm{a} P \mathrm{i}
\end{array}
$$

do not contrast in margins in any language do not contrast in margins in any language do not contrast in nuclei in any language do not contrast in nuclei in any language

Similar limitations seem to hold for lateral and nasal release and for ATR/RTR distinctions on consonants as well as nasalization and ATR/RTR distinctions on vowels, and we suspect that these too are prosodically licensed, though that is not something we can yet claim with confidence. Prosodic licensing of this kind leaves the notion segment pretty much gutted except for the physiologically necessary but not necessarily one-to-one pairing of place and manner. We call such a minimal pairing between place and manner a seglet and propose that a model with seglets rather than segments comes closer to modelling the contrasts we find in the languages of the world. Put another way, we claim that place is licensed by manner and everything else (including manner) is licensed by prosody:

3 Notice though that feature theories which assume that palatal(ization) and velar(ization) are produced with different articulators (coronal and dorsal, respectively) will have to stipulate that both cannot cooccur in a single onset or coda. Feature models subscribing to the traditional view of all vowels being dorsal can do with a more general ban on antagonistic feature specifications *[-back][+back], or *[front][back] in privative terms. 
(13) Bottlebrush margins

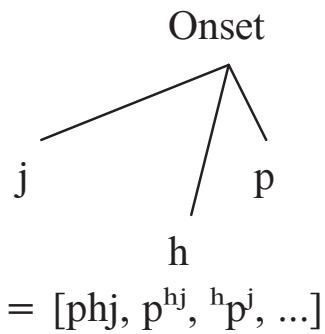

$(j, h$, and $p$ are short hand for sets of vocalic $(j)$, laryngeal $(h)$, and consonantal (p) features, and are phonologically unordered within syllable margins.)

The rest of the chapter is organized as follows. In $\S 1$ we motivate the general claim that the vocalic contrasts found in languages do not increase with the segmental complexity of the margin: $\mathrm{CC}$, and $\mathrm{CCC}$ margins show the same range of vocalic options that simple $\mathrm{C}$ margins show, making it unlikely that every consonant has its own set of vocalic features. In $\S 2-\S 4$ we substantiate the three more specific claims in 2-4 above: that languages countenance no conflicting vocalic contrasts within a margin $\left(*{ }_{\mathrm{j} u},{ }^{* \mathrm{j}} \mathrm{p}^{\mathrm{y}}\right.$, etc. $)$, no pre/post contrasts within a margin $\left({ }^{\mathrm{j}} \mathrm{p} \sim \mathrm{p}^{\mathrm{j}}, \mathrm{jp} \sim \mathrm{pj}\right.$, etc. $)$, and no segment/cluster contrasts within a margin $\left(p^{j} \sim p j, p^{j} \sim p t j\right.$, etc.). We then consider languages that look at first problematic for our proposals $(\S 5)$, show how prosodic licensing constrains processes of assimilation $(\S 6)$, and end with some theoretical implications of our results $(\$ 7)$.

\section{Complex margins are vocalically simple}

Simple margins can have up to six distinct types of contrastive vocalic settings: plain $(\varnothing, p)$, palatal $\left(j, p^{j}\right)$, velar $\left(u, p^{\searrow}\right)$, labial $\left(\beta, p^{\beta}\right)$, labio-palatal $\left(ч, p^{4}\right)$, and labio-velar $\left(w, p^{w}\right)$ (Ladefoged \& Maddieson 1996). ${ }^{4}$ These can be analyzed with three privative features, [front], [back], and [round], along with a co-occurrence restriction against the antagonistic combination $*[$ front, back].

(14) Glides and secondary vocalics

\begin{tabular}{|l|l|l|l|}
\hline & -- & {$[$ front $]$} & {$[$ back $]$} \\
\hline--- & $\mathrm{p}$ & $\mathrm{j}, \mathrm{p}^{\mathrm{j}}$ & u, $\mathrm{p}^{\mathrm{\gamma}}$ \\
\hline [round] & $\beta, \mathrm{p}^{\beta}$ & ч, $\mathrm{p}^{\mathrm{u}}$ & $\mathrm{w}, \mathrm{p}^{\mathrm{w}}$ \\
\hline
\end{tabular}

4 Again, we exclude pharyngeal (or radical) coarticulation to keep the scope of this paper manageable; our prediction, of course, is that pharyngeal coarticulation patterns exactly like palatal, velar, and labial coarticulation. 
We start by looking at languages which allow for glide-only margins. Maddieson's (1984) database contains glides at all five places, albeit with markedly different frequencies.

(15) Approximants in Maddieson (1984)

\begin{tabular}{|l||c|c|c|c|c|}
\hline places & palatal & labio-velar & labial & velar & labio-palatal \\
\hline \hline & $\mathrm{j}$ & $\mathrm{w}$ & $\beta$ & u & Ч \\
\hline number of languages & 271 & 238 & 6 & 5 & 4 \\
\hline percent of languages & $86.1 \%$ & $75.7 \%$ & $1.9 \%$ & $1.6 \%$ & $1.3 \%$ \\
\hline
\end{tabular}

The frequencies above are roughly comparable to those of the corresponding high vowels ( $\mathrm{i}, \mathrm{u}, \dot{\mathrm{i}} / \mathrm{u}, \mathrm{y}$ ) in Maddieson's database, supporting the generally accepted assumption of glides as the non-syllabic counterparts of high vowels. There is one notable asymmetry, though: since vowels are always produced with some tongue body articulation, there is no syllabic sound corresponding to the labial glide $[\beta]$.

Below we give examples from languages having from two to four glides in their inventory. We are not aware of a language using all five glides. Notice, though, that all individual contrasts seem to be attested, including contrasts of $[\beta]$ and $[\mathrm{w}]$.

(16) Languages with two glides 5

\begin{tabular}{|l|c|c|c|c|c|}
\hline & front & back & round & $\begin{array}{c}\text { front, } \\
\text { round }\end{array}$ & $\begin{array}{c}\text { back, } \\
\text { round }\end{array}$ \\
\hline $\begin{array}{l}\text { Adzera, Bini (Edo), English, Igbo, } \\
\text { Kashmiri, Kihehe, Klamath, Korean, } \\
\text { Kutep, Luganda, Polish, Temne, Toda }\end{array}$ & $\mathrm{j}$ & & & & $\mathrm{w}$ \\
\hline $\begin{array}{l}\text { Hindi-Urdu, Karok, Nzima, Sámi, } \\
\text { Telugu, Karacalar Ubykh, Yatée Zapotec }\end{array}$ & $\mathrm{j}$ & & $\beta$ & & \\
\hline
\end{tabular}

5 Adzera (Howard 2010). Kashmiri (Bhaskararao et al. 2009), Klamath (Barker 1964), Nzima (Ladefoged 1964: $\beta$ alternates between $[\mathrm{w} \sim \mathrm{\Psi}]$ ), Temne (Kanu \& Tucker 2010), Karacalar Ubykh (Dumézil 1965). Other data from Ladefoged 1964 and Maddieson 1984. 
(17) Languages with three glides 6

\begin{tabular}{|l||c|c|c|c|c|}
\hline & front & back & round & $\begin{array}{c}\text { front, } \\
\text { round }\end{array}$ & $\begin{array}{c}\text { back, } \\
\text { round }\end{array}$ \\
\hline Axininca Campa, Mazatec & $\mathrm{j}$ & $\mathrm{u}$ & $\beta$ & & \\
\hline $\begin{array}{l}\text { Aranda, Cofan, Kanakuru, Margi, } \\
\text { Marshallese, Lillooet, Shuswap, Wiyot }\end{array}$ & $\mathrm{j}$ & $\mathrm{u}$ & & & $\mathrm{w}$ \\
\hline Abkhaz, Lakkia, Twi & $\mathrm{j}$ & & $\beta$ & $\mathrm{\Psi}$ & \\
\hline Shona & $\mathrm{j}$ & & $\mathrm{v}$ & & $\mathrm{w}$ \\
\hline $\begin{array}{l}\text { Breton, Fante, French, Gã, Iaai, Western } \\
\text { Idoma, Kom, Mandarin, Tikar }\end{array}$ & $\mathrm{j}$ & & & $\mathrm{\Psi}$ & $\mathrm{w}$ \\
\hline
\end{tabular}

(18) Languages with four glides ${ }^{7}$

\begin{tabular}{|l||c|c|c|c|c|}
\hline & front & back & round & $\begin{array}{c}\text { front, } \\
\text { round }\end{array}$ & $\begin{array}{c}\text { back, } \\
\text { round }\end{array}$ \\
\hline Dschang & $\mathrm{j}$ & щ & & $\mathrm{u}$ & $\mathrm{w}$ \\
\hline
\end{tabular}

Margins with a single consonantal articulation occur with the same set of maximally six vocalic series (including Ø), as we see in the following tables. ${ }^{8}$ Note the complete absence of languages that contrast only plain and velarized margins $\left(p \sim p^{\curlyvee}\right)$ :

6 Axininca Campa (Payne 1981), Iaai (Maddieson \& Anderson 1994), Lakkia (Haudricourt 1967), Mandarin (Duanmu 1999), Marshallese (Choi 1992), Mazatec (Golston \& Kehrein 1998), Shona (Mudzingwa 2010), Tikar (Westermann \& Bryan 1952; cited in Laver 1994), Twi (de Jong \& Obeng 2000). Other data from Ladefoged 1964 and Maddieson 1984.

7 Dschang (Bird 1999). Ladefoged (1964) says that the Bini (Edo) contrasts bilabial [v], velar [ $\left.\gamma^{\top}\right]$, labial velar $[\mathrm{w}]$ and palatal [j] glides, though $[\mathrm{v}]$ and $\left[\mathrm{\gamma}^{\top}\right]$ seem nowadays to be treated as the voiced fricatives $[\beta]$ and $[\mathrm{\gamma}]$ in Edoid languages.

8 In the tables that follow, languages are included which show a contrast at at least one place of articulation. For simplicity, we show the contrasts using labials, but this should not be taken to imply that only labials show these contrasts. Coronals and velars are given when labials fail to show the maximal number of contrasts. 
(19) Two series of vocalically simple margins ${ }^{9}$

\begin{tabular}{|c|c|c|c|c|c|c|}
\hline & plain & front & back & labial & $\begin{array}{l}\text { front, } \\
\text { labial }\end{array}$ & $\begin{array}{l}\text { back, } \\
\text { labial }\end{array}$ \\
\hline $\begin{array}{l}\text { Bulgarian, Irish, Kashmiri, } \\
\text { Lithuanian, Nenets, Ocaina, Polish, } \\
\text { Russian, Resigaro }\end{array}$ & $\mathrm{p}^{(\mathrm{y})}$ & $\mathrm{p}^{\mathrm{j}}$ & & & & \\
\hline $\begin{array}{l}\text { Amharic, Archi, Awiya, Beja, Bella } \\
\text { Coola, Caddo, Upper Chehalis, } \\
\text { Cuna, Dahalo, Dani, Diegueno, } \\
\text { Guambiano, Guarani, Hadza, Haida, } \\
\text { Hopi, Huasteco, Huave, Iranxe, } \\
\text { Iraqw, Kpelle, Kohumono, Konyagi, } \\
\text { Kolokuma Ijo, Kwaio, Kwakw'ala, } \\
\text { Kwoma, Lak, Lenakel, Luiseno, } \\
\text { Lushootseed, Yessan Mayo, Mixtec, } \\
\text { Movima, Nahuatl, Southern } \\
\text { Nambiquara, Navajo, Ngizim, } \\
\text { Nootka, Paya, Picuris, Pohnpeian, } \\
\text { Quileute, Rutul, Saliba, Shuswap, } \\
\text { Siona, Sui, Taishan, Tarascan, } \\
\text { Ticuna, Tlingit, Tonkawa, Tseshaht, } \\
\text { Wantoat, Warao, Wichita, Wiyot, } \\
\text { Yupik, Zuni }\end{array}$ & $\mathrm{p}$ & & & & & $\mathrm{p}^{\mathrm{w}}$ \\
\hline
\end{tabular}

(20) Three series of vocalically simple margins 10

\begin{tabular}{|l|c|c|c|c|c|c|}
\hline & plain & front & back & labial & $\begin{array}{c}\text { front, } \\
\text { labial }\end{array}$ & $\begin{array}{c}\text { back, } \\
\text { labial }\end{array}$ \\
\hline $\begin{array}{l}\text { Amuzgo, Bura, Hausa, Igbo, Kam, } \\
\text { Lai, Lakkia, Luganda, Margi, }\end{array}$ & $\mathrm{p}$ & $\mathrm{p}^{\mathrm{j}}$ & & & & $\mathrm{p}^{\mathrm{w}}$ \\
\hline
\end{tabular}

9 Irish (Ní Chiosáin 1999), Kashmiri (Bhaskararao et al. 2009), Lithuanian (Ambrazas 1997), Nootka (Stonham 1999); others from Kochetov 2008, based on Maddieson \& Precoda 1990.

10 Bura (Ladefoged 1964), Hausa (Schuh \& Yalwa 1993; three-way contrast only before [a]) Igbo (Clark 1990), Lakkia (Haudricourt 1967), Luganda (Ladefoged 1971), Margi (Hoffman 1963), Zoque (Wonderly 1951). Ubykh (Catford 1977), Scottish Gaelic (Ladefoged et al. 1998), Northern Irish (Ní Chiosáin 1999), Nupe (Hyman 1970), Late and Nzima (Ladefoged 1964), Marshallese (Willson 2003). Others from Kochetov 2008, based on Maddieson \& Precoda 1990. 


\begin{tabular}{|l||c|c|c|c|c|c|}
\hline & plain & front & back & labial & $\begin{array}{c}\text { front, } \\
\text { labial }\end{array}$ & $\begin{array}{c}\text { back, } \\
\text { labial }\end{array}$ \\
\hline $\begin{array}{l}\text { Nambakaengo, Tera, Tsimshian, } \\
\text { Zoque }\end{array}$ & & & & & & \\
\hline Ubykh $^{11}$ & $\mathrm{q}$ & $\mathrm{q}^{\mathrm{j}}$ & & $\mathrm{q}^{\mathrm{\beta}}$ & & \\
\hline Scottish Gaelic, Northern Irish, Nupe & 1 & $\mathrm{1}^{\mathrm{j}}$ & $\mathrm{1}^{\mathrm{y}}$ & & & \\
\hline Late, Nzima & $\mathrm{t}$ & & & & $\mathrm{cc}^{\mathrm{w}}$ & $\mathrm{n}^{\mathrm{w}}$ \\
\hline Marshallese & & $\mathrm{n}^{\mathrm{j}}$ & $\mathrm{n}^{\mathrm{y}}$ & & & $\mathrm{n}^{\mathrm{w}}$ \\
\hline
\end{tabular}

(21) Four series of vocalically simple margins ${ }^{12}$

\begin{tabular}{|l||c|c|c|c|c|c|}
\hline & plain & front & back & labial & $\begin{array}{c}\text { front, } \\
\text { labial }\end{array}$ & $\begin{array}{c}\text { back, } \\
\text { labial }\end{array}$ \\
\hline Birom, Kutep, Twi & $\mathrm{p}$ & $\mathrm{p}^{\mathrm{j}}$ & & $\mathrm{p}^{\beta}$ & $\mathrm{p}^{\mathrm{y}}$ & \\
\hline Mazatec & $\mathrm{t}$ & $\mathrm{t}^{\mathrm{j}}$ & $\mathrm{t}^{\mathrm{y}}$ & $\mathrm{t}^{\mathrm{\beta}}$ & & \\
\hline Shona & $\mathrm{t}$ & $\mathrm{t}$ & & $\mathrm{ts}^{\beta}$ & & $\mathrm{m}^{\mathrm{w}}$ \\
\hline Mandarin & $\mathrm{ts}$ & $\mathrm{t} 6$ & & & $\mathrm{t}^{\mathrm{4}}$ & $\mathrm{ts}^{\mathrm{w}}$ \\
\hline
\end{tabular}

(22) Five series of vocalically simple margins ${ }^{13}$

\begin{tabular}{|l||c|c|c|c|c|c|}
\hline & plain & front & back & labial & $\begin{array}{c}\text { front, } \\
\text { labial }\end{array}$ & $\begin{array}{c}\text { back, } \\
\text { labial }\end{array}$ \\
\hline Kom & $\mathrm{t}$ & $\mathrm{t} 6$ & $\mathrm{dy}$ & $\mathrm{t}^{\mathrm{\beta}}$ & $\mathrm{t}^{\mathrm{f}}$ & \\
\hline
\end{tabular}

The tables above require some comment: first, not all languages have all secondary vocalic articulations with every consonant: we use 'p' as a cover-symbol for consonants at various points of articulation to simplify the presentation. Second, palatalization and velarization often shift primary (consonantal) places, such that coronals $[t, t s, s]$, for instance, have

11 In addition, Ubykh had (the language is extinct) pharyngealized uvulars $\left[\mathrm{q}^{\S}\right]$ and labio-pharyngealized

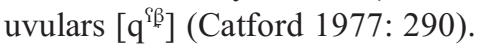

12 Birom (Ladefoged 1964: $\mathrm{k} \sim \mathrm{c} \sim \mathrm{k} \beta \sim \mathrm{c} \beta$ ), Kutep (Ladefoged 1964: $\mathrm{ts} \sim \mathrm{tf} \sim \mathrm{ts}^{\mathrm{f}} \sim \mathrm{tc}_{6}^{\mathrm{f}}$ ), Twi (De Jong \& Obeng 2000: only before front vowels), Mazatec (Golston \& Kehrein 1998), Shona (Mudzingwa 2010), Mandarin (Duanmu 2000).

13 Kom (Ladefoged 1964). 
palatalized variants at postalveolar $\left[\mathrm{t}, \mathrm{t}, \int\right]$ or alveolo-palatal places $[\mathrm{t}, \mathrm{c}, \mathrm{\epsilon}]$, and retroflexes $[\mathrm{t}$ ts, s] as their velarized counterparts (Hall 1997, Kochetov 2002, among others). Likewise, palatalized and velarized velars $[\mathrm{k}, \mathrm{x}, \mathrm{y}]$ can be produced at palataloalveolar $\left[\mathrm{t}, \mathrm{t} f, \int, \underline{\mathrm{n}}\right]$ (or palatal $[\mathrm{c}, \mathrm{c}, \mathrm{n}])$ and uvular $[\mathrm{q}, \chi, \mathrm{N}]$ places, respectively. Notice also that our treatments of Mazatec and Mandarin are not the standard ones: we assume that nucleic glides in the standard treatment are actually part of the onset, as argued for Mazatec by Golston \& Kehrein 1998 (contra Pike \& Pike 1947, Steriade 1994) and for Mandarin by Duanmu (2000:480); we come back to the discussion of syllable structure below.

When we turn to complex (CC and CCC) onsets and codas, we find that they allow the same or fewer vocalic contrasts as simple margins do: the addition of extra consonants within a margin does not open up additional secondary vocalic possibilities. This is an unexpected finding from a segmental perspective, and it strongly suggests that there is a single set of vocalic features per syllable margin (1), whether that margin is simple or complex.

Thus, Irish (Ní Chiosáin 1999), Lithuanian (Ambrazas 1997), and Russian have plain (or velarized) consonants [t] and palatalized consonants [ $\left.\mathrm{t}^{\mathrm{j}}\right]$ as well as plain [st] and palatalized onset clusters $\left[\mathrm{s}^{\mathrm{j}} \mathrm{t}^{\mathrm{j}}\right]$, as shown in (23). (The full picture is slightly more complicated in Lithuanian and Irish, and much more complicated in Russian. We return to these languages in later sections to give a more thorough description of how palatalization is realized in different types of complex onsets and codas.)

(23) Series of vocalized complex onsets

\begin{tabular}{|c|c|c|c|}
\hline & plain & front & labial \\
\hline Irish, Lithuanian, Russian & $\mathbf{s}^{(\mathrm{y})} \mathbf{t}^{(\mathrm{y})}$ & $s^{j} t^{j}$ & \\
\hline Kashmiri & $\mathrm{mp}$ & $m^{j} p^{j}$ & \\
\hline Kabardian & $\begin{array}{l}\mathrm{px} t \mathrm{t} \\
\mathrm{p} \chi \mathrm{t} \chi\end{array}$ & & $\begin{array}{c}p^{\beta} x^{\beta} t^{\beta} x^{\beta} \\
p^{\beta} \chi^{\beta} \quad t^{\beta} \chi^{\beta}\end{array}$ \\
\hline Abadzakh & sk sq sx s $\chi$ & & $\begin{array}{ll}s^{\beta} k^{\beta} & s^{\beta} q^{\beta} \\
s^{\beta} x^{\beta} & s^{\beta} \chi^{\beta}\end{array}$ \\
\hline
\end{tabular}

Kashmiri (Bhaskararao et al. 2009) has plain consonants [p] and palatalized consonants $\left[\mathrm{p}^{\mathrm{j}}\right]$ as well as plain [mp] and palatalized coda clusters $\left[\mathrm{m}^{\mathrm{j}} \mathrm{p}^{\mathrm{j}}\right]$, but nothing more detailed than that, in part because "palatalization spreads across the whole of the consonant stretch to which it is attached" (Bhaskararao et al. 2009:14). Kabardian (Catford 1972, Kuipers 1960, Henderson 1970) and Abadzakh (Paris 1989) have plain [p] and labialized [p $\mathrm{p}^{\beta}$ ] as well as 
plain $[\mathrm{px}]$ and labialized onset clusters $\left[\mathrm{p}^{\beta} \mathrm{x}^{\beta}\right] \cdot{ }^{14}$ Again, complex margins do not open up additional vocalic possibilities that simplex margins lack: we do not find tricky four-way contrasts like $\left[s \chi \sim s^{\beta} \chi \sim s \chi^{\beta} \sim s^{\beta} \chi^{\beta}\right.$, merely simple two-way contrasts like $\left[s \chi \sim s^{\beta} \chi^{\beta}\right]$.

Limitations of space keep us from rehearsing such facts for all of the languages with secondary articulations and CC or CCC syllable margins, but the examples above are to our knowledge entirely representative of the facts generally. Aside from a few cases we discuss below, we know of no languages in which there is any reason to think that complex margins beget additional secondary articulations that simplex margins lack.

\section{No conflicting vocalic contrasts within a margin}

Despite an extensive search we have been unable to find a single language in which palatalization and velarization occur within the same onset or coda. This is expected for simple margins because even standard theory posits only a single set of vocalic features per consonant. This rules out $*\left[{ }^{\mathrm{j}} \mathrm{p}^{\mathrm{y}}\right] *\left[\mathrm{~m}^{\mathrm{j} \mathrm{y}}\right]$, and the like as simple margins. More interesting is the lack of complex margins like $*[j u]],{ }^{*}\left[p^{j} 1^{\gamma}\right],{ }^{*}\left[p^{j} u\right]$, etc., To rule these out we need to restrict the vocalic possibilities of complex margins to those of simple margins, as proposed here.

Languages do not seem to combine palatal (front) and velar (back) glides within a single onset or coda *[ju] either. There appear to be a few counterexamples to this claim, but they all turn out to be due to mere orthographic conventions combining ' $j$ ' with ' $w$ ' to represent $[\mathrm{y}]$ or some similar sound. In other words: in these cases, 'w' marks a labial but not a velar articulation, so the sound is [round, front], but not *[round, front, back]. Zoque (Wonderly 1951), for instance, has $/ \mathrm{j} /$ and /w/ (the latter described as 'bilabial, rounded', $\mathrm{p}$. 107) and 'wj' as well, which however represents something like $/ \beta^{\mathrm{j} /:}$ 'The cluster wy is actualized as an unrounded bilabial spirant with the tongue in palatal position' (Wonderly 1951:107). Whatever the appropriate phonetic and/or phonological description of 'wy' in Zoque, the phonetic description makes it clear that the sound under question is palatal/front but in no way velar/back.

Similarly, Lakkia (Haudricourt 1967) is said to have /w/, /j/ and /jw/. Again, the latter does not represent a combination of palatal and velar articulations; rather ' $w$ est une labialization, j une palatalization' (p. 169, footnote 1). Lakkia $\langle w>$ is a labial glide $/ \beta /$,

14 "It must be stressed that although the phonetic transcription used follows Catford in indicating labialization by the letter $\mathrm{w}$ after the symbols for the clustered consonants, this does not imply a separate labial glide following the cluster. Labialization when it occurs is of the whole cluster, and frequently extends also to the following vowel." (Henderson 1970: 102) 
and $<\mathrm{jw}>$ is just a rounded palatal / $\mathrm{u} /$. Bzyb and Southern Abkhaz (Chirikba 1996) are said to have $/ \mathrm{j}, \mathrm{w} /$, and $/ \mathrm{j}^{\mathrm{w}} /$, but again $\langle\mathrm{w}\rangle$ is a purely labial glide $/ \beta /$, and $\left\langle\mathrm{j}^{\mathrm{w}}\right\rangle$ is actually / $\mathrm{q}$ : 'The symbol $\mathrm{y}$ represents a labial plus palatal semivowel, exactly like the initial French sound of huit.' (Catford 1977: 291)

Klamath presents a slightly different case (Barker 1964). The language has /w, $\mathrm{j} /$ as well as a word-initial 'cluster' $/ \mathrm{w}+\mathrm{j} /$. In this case, however, [w] is syllabic, realized as [wu] according to Barker, and the velar and palatal articulations are heterosyllabic. All of this is summarized in (24).

(24) Apparent glide clusters in single margins

\begin{tabular}{|l|c|c|}
\hline & orthographic & phonetic \\
\hline Zoque & wy & $\beta^{\mathrm{j}}$ \\
\hline Lakkia & $\mathrm{jw}$ & $\mathrm{\Psi}$ \\
\hline Abkhaz & $\mathrm{j}^{\mathrm{w}}$ & $\mathrm{\Psi}$ \\
\hline Klamath & wj & w.j \\
\hline
\end{tabular}

As for secondary palatalization and velarization, we are not aware of a counterexample to our claim in (2). This comes as a real surprise from the perspective of segmental licensing, for nothing in segmental licensing explains why a language with palatalized and velarized consonants and complex CC margins should not have, say, $\left[\mathrm{p}^{\mathrm{j}} \mathrm{t}^{\mathrm{\gamma}}\right],\left[\mathrm{p}^{\mathrm{\gamma}}\right],\left[{ }^{\mathrm{j}} \mathrm{pt}^{\mathrm{\gamma}}\right]$, or the like. Our claim in (1) that each onset and coda has a single unordered set of vocalic features captures this right away, along with the lack of syllable margins like [jw], [ju]], [чщு], and their ilk.

\section{No pre/post contrasts within a margin}

Secondary articulations of consonants (aspiration, ejection, palatalization, velarization, etc.) are conventionally written with superscripts after the respective consonant symbol $\left[p^{\mathrm{h}}, \mathrm{p}^{\mathrm{j}}, \mathrm{p}^{\mathrm{j}}\right.$, $\mathrm{p}^{\mathrm{\gamma}}$, presumably because these features are "often more apparent at the release than at the formation of a primary constriction" (Ladefoged \& Maddieson 1996:363). This is not to say, however, that secondary articulations cannot start before the primary constriction is formed. In this section we look at a few languages in which we find secondary vocalic articulations before, after, and overlapping the primary consonant articulation. In no case are these timing differences contrastive, per our claim in (3).

(25)-(27) show different timings of labial and palatal gestures of Russian $\left[\mathrm{p}^{\mathrm{j}}\right]$ in intervocalic, word-initial, and word-final position, respectively (from Kochetov 1999). The 
word-medial case (25) shows the palatal articulation slopping over both sides of the labial closure, i.e. a pre- and postpalatalized stop $\left[{ }^{\mathrm{j}} \mathrm{p}^{\mathrm{j}}\right]$ (or $\left[{ }^{\mathrm{j}} \mathrm{p}^{\mathrm{j}}\right]$ in a more narrow phonetic transcription that includes the duration difference between on-glide and off-glide).

(25) consonantal and vocalic gestures of $\left[\mathrm{a}^{\mathrm{j}} \mathrm{p}^{\mathrm{j}} \mathrm{a}\right]$ (Kochetov 1999:182)

Lips

labial

TB

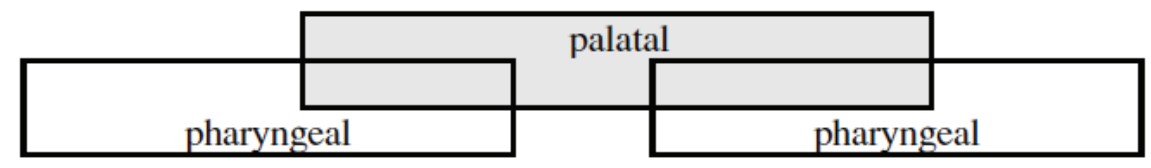

The word-initial case (26) has palatalization only after the stop is released, hence postpalatalized $\left[p^{\mathrm{j}}\right]$.

(26) consonantal and vocalic gestures of [ $\left.\mathrm{p}^{\mathrm{j} a}\right]$ (Kochetov 1999:183)

Lips

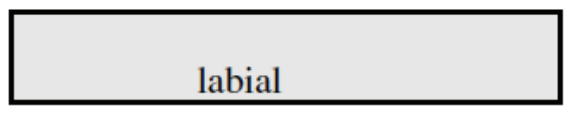

TB

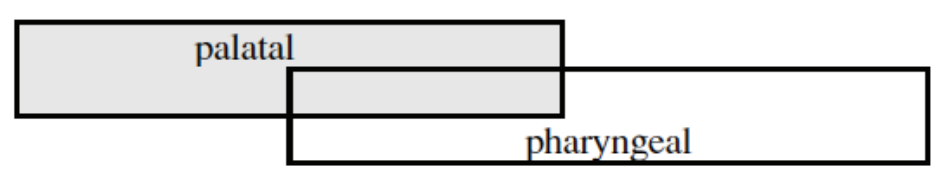

Gestural overlap in word-final position (27) resembles the intervocalic case, but the amount of audible postpalatalization depends on whether or how strongly the labial closure is released in this position: ' $[\mathrm{t}]$ he palatal glide at the right edge is devoiced and turned into a short component [ç], which represents an audible friction' (Kochetov 1999:183, after Jones \& Ward 1969). Thus, word-final $/ \mathrm{p}^{\mathrm{j}} /$ in Russian is regularly prepalatalized and postfricated $\left[{ }^{\mathrm{j}} \mathrm{p}^{\mathrm{c}}\right]$.

(27) consonantal and vocalic gestures of $\left[\mathrm{a}^{\mathrm{j}} \mathrm{p}^{\mathrm{c}}\right]$ (Kochetov 1999:183)

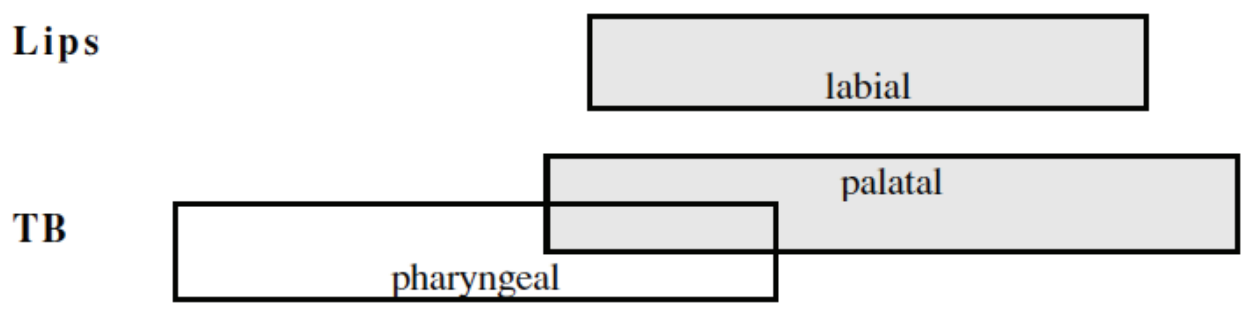

The acoustic effects of these different timing options $\left[{ }^{j} \mathrm{p}^{j}, \mathrm{p}^{\mathrm{j}},{ }^{\mathrm{j}} \mathrm{p}^{(\mathrm{s})}\right]$ can be seen in spectrograms from Hupa $\left[{ }^{\mathrm{j}} \mathrm{k}^{\mathrm{j}}\right]$ and Russian $\left[\mathrm{p}^{\mathrm{j}}\right]$ and $\left[{ }^{\mathrm{j}} \mathrm{t}\right]$. 
(28) Hupa $\left[{ }^{\mathrm{j}} \mathrm{k}^{\mathrm{j}}\right]$ (Gordon 2001: 32) (arrow marks palatal transitions into the velar closure)

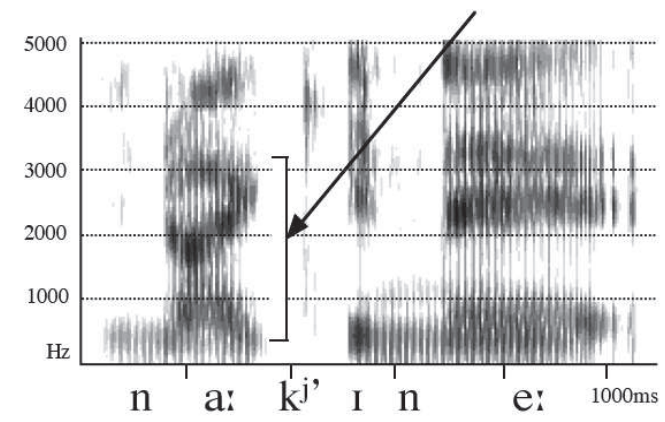

(29) Russian $\left[p^{j} a^{j} t^{(s)}\right]$ (Kochetov 1999: 178) (circles mark F2 changes in $\left[{ }^{j} a^{j}\right]$ )

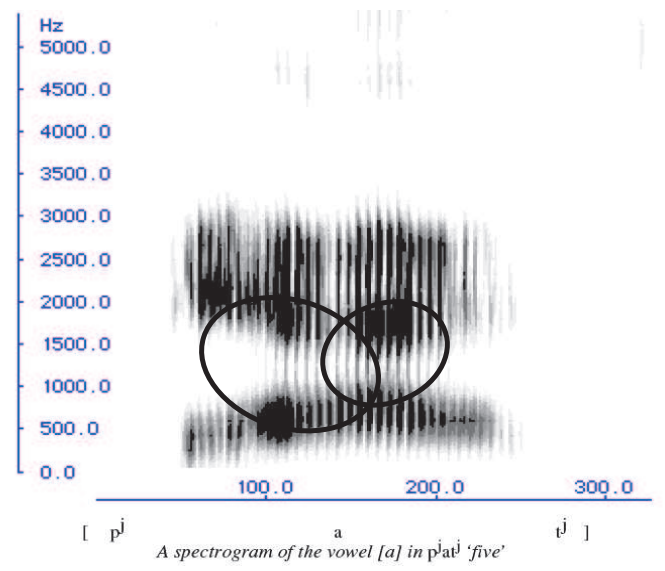

Marshallese (Choi 1992) is another language with simple margins that are simultaneously prevocalized and postvocalized. The language has a vertical vowel system /i, ə, e/, three glides /j, u, w/, and a simple system of basic consonants: /p, t, k, m, n, y, 1, r/. Only the velars $/ \mathrm{k}, \mathrm{y} /$, however, may surface without secondary vocalic articulations; all other consonants are either palatalized, velarized, or labio-velarized:

(30) Marshallese consonant inventory (Choi 1992: 14)

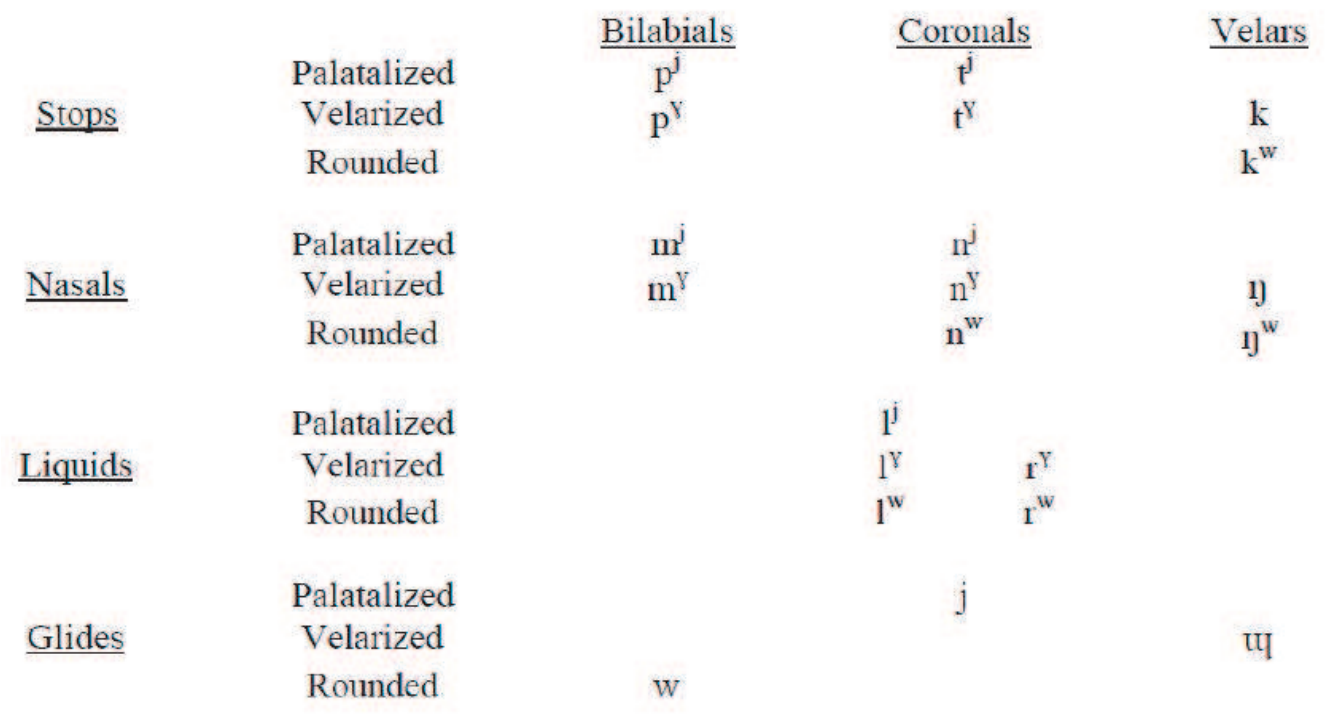


Secondary features of consonants show distinct coarticulatory effects on neighboring vowels: vowels are fronted next to palatalized consonants, retracted next to velarized consonants, and retracted-and-rounded next to labio-velarized consonants. Importantly, as shown below, coarticulation is both perseverative and anticipatory in the coda, i.e. while initial consonants are postpalatalized $\left[\mathrm{p}^{\mathrm{j}}\right]$, postvelarized $\left[\mathrm{p}^{\mathrm{Y}}\right]$, and postlabiovelarized $\left[\mathrm{k}^{\mathrm{w}}\right]$, final consonants (by and large) show the secondary articulations on both sides of the closure:

(31) Vowel qualities in $C^{x} V C^{y}$ words (asymmetric contexts; Choi 1992: 16)

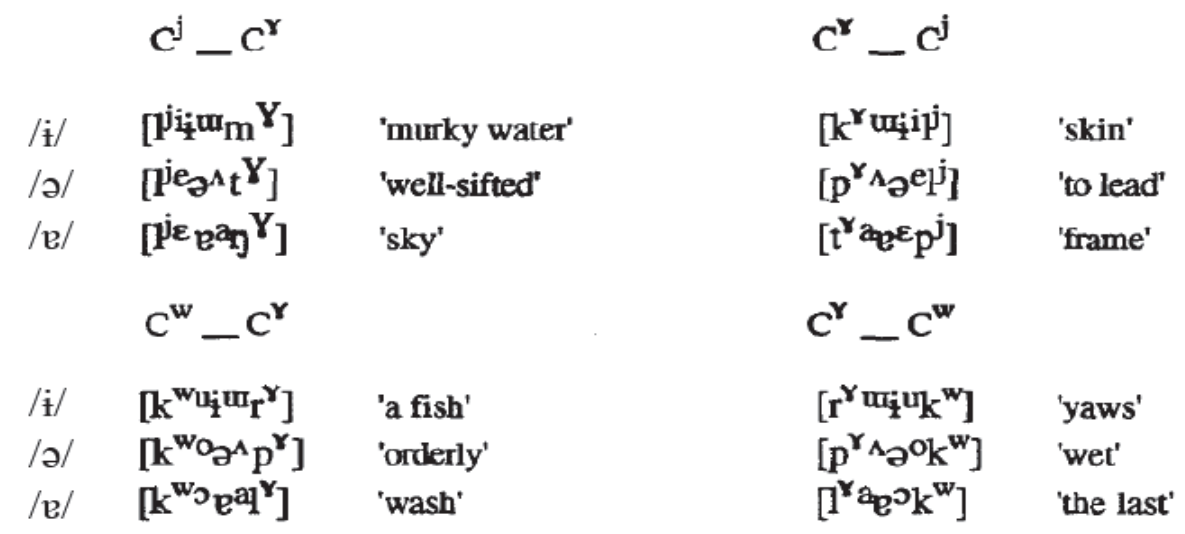

We see for instance that velarized stops in the coda (left-most columns in 31) have back onglides, [ [", $\left.{ }^{\wedge},{ }^{a}\right]$, while palatalized stops have front onglides $\left[{ }^{\mathrm{i}},{ }^{\mathrm{e}},{ }^{\mathrm{e}}\right]$, and labialized stops have rounded onglides $\left[{ }^{\mathrm{u}},{ }^{\mathrm{o}},{ }^{\mathrm{j}}\right]$; all of this in addition to the $\left[{ }^{\mathrm{y}},{ }^{\mathrm{j}},{ }^{\mathrm{w}}\right]$ at the point of release. Ladefoged \& Maddieson (1996: 358-360) show a similar instance of a simultaneous preand post-labiovelarized consonant in Pohnpeian $\left[{ }^{\mathrm{w}} \mathrm{p}^{\mathrm{w}}\right]$. Again: the timing differences are not contrastive in any of these cases.

Some languages have pre- but no post- secondary vocalizations. Estonian (Lehiste 1965, Asu \& Teras 2009) has palatalized coronals and coronal clusters, though only in postvocalic position (word-medially and finally). Palatalization is phased early with respect to both single consonants and to clusters. 'Estonian has pre-palatalization: palatalization occurs before rather than after the consonant and is characterized by a longer i-like transition from vowel to consonant and a quality change in the first part of a single or geminate consonant or consonant cluster' (Asu \& Teras 2009: 368).

Higi ('Kamwe', Mohrlang 1972) has labialized stops, affricates and fricatives in onsets, all realized with prelabialization. Labialized stops and affricates are realized as coarticulated labial-dental stops in Higi and need not concern us here; but the fricatives are 
realized with prelabialization of the kind we are interested in, with an onglide to the fricative: 15

(32) Prelabialization in Higi (Mohrlang 1972)

\begin{tabular}{|l|l||l|l||l|l|}
\hline \multicolumn{2}{|l||}{ Stops } & \multicolumn{2}{l||}{ Affricates } & \multicolumn{2}{l|}{ Fricatives } \\
\hline \hline$\left[{ }^{\mathrm{p}}\right.$ tá $]$ & 'skin' & {$\left[{ }^{\mathrm{p}} \mathrm{tsi}\right]$} & 'grass' & {$\left[{ }^{\mathrm{w}}\right.$ sí] } & 'thing' \\
\hline$\left[{ }^{\mathrm{b}} \mathrm{di}\right]$ & 'to pour' & {$\left[{ }^{\mathrm{b}} \mathrm{dzi}\right]$} & 'strand' & {$\left[{ }^{\mathrm{w}} \mathrm{za}\right]$} & 'farming' \\
\hline
\end{tabular}

Place and manner specifications of consonants are another source of different gestural timings in secondary articulated consonants: with stops, nothing is audible during oral closure and thus some phase of a vocalic articulation will have to precede [ $\left.{ }^{\mathrm{w}} \mathrm{t}\right]$ or follow $\left[\mathrm{t}^{\mathrm{w}}\right]$ closure in a palatalized or velarized stop in order to be perceived. For other consonants, however, both gestures can be perceived simultaneously, such that $\left[\mathrm{n}^{\mathrm{w}}, \mathrm{l}^{\mathrm{w}}, \mathrm{s}^{\mathrm{w}}\right]$ do not necessarily require vocalic on-glides or off-glides (though they typically have them). As for consonantal place, there is a difference between $\left[\mathrm{p}^{\mathrm{j}}\right]$, produced with two independent articulators (lips and tongue), and $\left[\mathrm{p}^{\mathrm{w}}\right],\left[\mathrm{t}^{\mathrm{j}}\right]$, or $\left[\mathrm{k}^{\mathrm{j}}\right]$, using the same or at least anatomically joined articulators. Palatalization of coronals $\left[\mathrm{t}^{\mathrm{j}}, \mathrm{s}^{\mathrm{j}}, \mathrm{n}^{\mathrm{j}}\right]$ and velars $\left[\mathrm{k}^{\mathrm{j}}, \mathrm{x}^{\mathrm{j}}, \mathrm{n}^{\mathrm{j}}\right]$ often results in a shift of the primary articulator, from alveolar to palato-alveolar $\left[\mathrm{t} / \mathrm{t} f, \int, \mathrm{n}\right]$ or alveopalatal [te, c], and from velar to palatal [c, ç, n] — with slight or no audible off-glides. (Similarly for velarization of coronal to retroflex and of velar to uvular.)

Crucially for present purposes, none of these timing differences are used to form contrasts in any language we know of: a language can have postvocalized single margins $\left[\mathrm{p}^{\mathrm{j}}\right.$, $\left.\mathrm{n}^{\mathrm{w}}, \mathrm{t}^{\mathrm{b}}\right]$, or prevocalized single margins $\left[{ }^{\mathrm{j}} \mathrm{p},{ }^{\mathrm{w}} \mathrm{n},{ }^{\mathrm{x}} \mathrm{t}\right]$, or even both simultaneously $\left[{ }^{\mathrm{j}} \mathrm{p}^{\mathrm{j}},{ }^{\mathrm{w}} \mathrm{n}^{\mathrm{w}},{ }^{\mathrm{y}} \mathrm{t}^{\mathrm{y}}\right]$; but the pre-post issue is always a matter of complementary distribution, depending on position, e.g. $\left[\mathrm{p}^{\mathrm{j}} \mathrm{a}^{\mathrm{j}} \mathrm{p}^{\mathrm{j}} \mathrm{a}^{\mathrm{j}} \mathrm{p}\right.$, or the type of consonant involved, e.g., [f] vs. [S]. Again, the contrasts we find in languages are compatible with a syllable margin having a single set of secondary vocalic features that may precede, overlap, or follow the primary consonant $\operatorname{articulation}(\mathrm{s})$.

Some languages use more than one phasing option in complex constituents, i.e. they have prepalatalized and postpalatalized complex margins, or prevelarized and postvelarized complex margins. As with simple constituents, however, these timing differences are not contrastive but always a matter of phonetic variation depending on syllable position or the

15 Labial stops as an extreme form of postlabialization are attested with alveolars in Abkhaz and Ubykh: $/ \mathrm{t}^{\mathrm{w}}$, $\mathrm{t}^{\mathrm{w}}, \mathrm{d}^{\mathrm{w}} /=[\mathrm{tp}, \mathrm{tp}, \mathrm{db}]$, but $/ \mathrm{k}^{\mathrm{w}}, \mathrm{q}^{\mathrm{w}}, \chi^{\mathrm{w}} /$ etc. $=\left[\mathrm{k}^{\beta}, \mathrm{q}^{\mathrm{\prime}}, \chi^{\beta}\right]($ Catford 1977). 
type of consonant involved, as far as we know. We start with the set of complex onsets in Irish: 16

(33) Complex onsets in Irish (from Ní Chiosáin 1999: 555ff)

\begin{tabular}{|c|c|c|}
\hline & plain & palatalized \\
\hline stop + 1: & pl bl tl dl $\mathrm{kl}$ gl & $p^{j} 1^{j} \quad b^{j} 1^{j} \quad t^{j} 1^{j} \quad d^{j} 1^{j} \quad k^{j} 1^{j} \quad g^{j} 1^{j}$ \\
\hline stop + r: & pr br tr $\mathrm{dr} \mathrm{kr}$ gr & 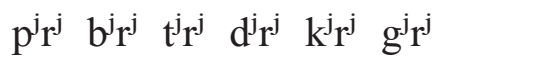 \\
\hline stop + N: & tn $\mathrm{kn}$ gn & $k^{j} n^{j} g^{j} n^{j}$ \\
\hline$N+C:$ & $\mathrm{mr} \mathrm{mn}$ & - \\
\hline fricative $+\mathrm{C}$ : & fl fr $\mathrm{sp}$ st $\mathrm{sk}$ sl $\mathrm{sr}$ sn $\mathrm{sm}$ & $\mathrm{f}^{\mathrm{j}} \mathrm{j}^{\mathrm{j}} \mathrm{f}^{\mathrm{j}} \mathrm{r}^{\mathrm{j}} \mathrm{sp}^{\mathrm{j}} \int \mathrm{t}^{\mathrm{j}} \int \mathrm{k}^{\mathrm{j}} \int \mathrm{l}^{\mathrm{j}} \int \mathrm{n}^{\mathrm{j}} \mathrm{sm}^{\mathrm{j}}$ \\
\hline s + stop + liquid: & spr $\quad$ spl $\quad$ str $\quad$ skr $\quad$ skl & $s p^{j} 1^{j} \quad s p^{j} r^{j} \quad \int t^{j} r^{j} \quad \int k^{j} r^{j} \quad \int^{j} k^{j} l^{j}$ \\
\hline
\end{tabular}

Onset clusters in Irish are generally well-behaved, either plain throughout or palatalized throughout. The four exceptions to this are $\left[\mathrm{sp}^{\mathrm{j}}, \mathrm{sm}^{\mathrm{j}}, \mathrm{sp}^{\mathrm{j}} \mathrm{l}^{\mathrm{j}}, \mathrm{sp}^{\mathrm{j}} \mathrm{r}^{\mathrm{j}}\right]$, i.e. clusters of plain $[\mathrm{s}]$ followed by a palatalized labial stop ( $\mathrm{p}$ or $\mathrm{m}$ ). These clusters illustrate an important aspect of our proposal: we claim that onsets and codas are phonologically plain or palatalized (or velarized, labialized, labiopalatalized, labiovelarized), but we do not claim that every consonant in an onset cluster is necessarily realized with a secondary vocalic feature. Our claim is rather that clusters with vocalic features realized early $\left(\mathrm{p}^{\mathrm{j} l}\right)$, late $\left(\mathrm{pl}^{\mathrm{j}}\right)$ or throughout $\left(\mathrm{p}^{\mathrm{j}} \mathrm{l}^{\mathrm{j}}\right)$ do not contrast with each other. This is true for Irish. The language contrasts [sp, sm, spl, spr] with $\left[\mathrm{sp}^{\mathrm{j}}, \mathrm{sm}^{\mathrm{j}}, \mathrm{sp}^{\mathrm{j}} \mathrm{l}^{\mathrm{j}}, \mathrm{sp}^{\mathrm{j}} \mathrm{r}^{\mathrm{j}}\right]$, but it has neither $*\left[\int \mathrm{p}, \int \mathrm{m}, \int \mathrm{pl}, \int \mathrm{pr}\right]$ nor $*\left[\int \mathrm{p}^{\mathrm{j}}, \int \mathrm{m}^{\mathrm{j}}, \int \mathrm{p}^{\mathrm{j}} \mathrm{l}^{\mathrm{j}}\right.$, $\left.\int \mathrm{p}^{\mathrm{j}} \mathrm{r}^{\mathrm{j}}\right]$, let alone any of the following: ${ }^{*}\left[\mathrm{sp}^{\mathrm{j}} 1, \mathrm{sp}^{\mathrm{j}} \mathrm{r}, \int \mathrm{p}^{\mathrm{j}} 1, \int \mathrm{p}^{\mathrm{j}} \mathrm{r}, \int \mathrm{pl}^{\mathrm{j}}, \int \mathrm{pr}^{\mathrm{j}}\right]$. As with other clusters then, the contrast is between plain and palatalized onsets; but palatalization does not extend over the entire cluster if labial stops $(\mathrm{p}, \mathrm{m})$ are involved.

Kochetov (1999) shows that (word-initial) $\mathrm{C}_{1} \mathrm{C}_{2}$ onsets in Russian can have plain and palatalized consonants in $\mathrm{C}_{2}$ (34), but only plain consonants in $\mathrm{C}_{1}(35)$.

\footnotetext{
16 Mutation and eclipsis increase the number of onsets in Irish significantly, but they do not change the general picture, for such clusters, too, are either plain or palatalized (see Ní Chiosáin 1999:557ff for examples).
} 
(34) plain vs. palatalized $C_{2}$ in Russian word-initial onsets (Kochetov 1999: 192-193)

\begin{tabular}{|c|c|c|c|c|c|}
\hline $\mathrm{p}$ & {$[\mathrm{sp}] \mathrm{at} \mathrm{t}^{\mathrm{j}}$} & 'to sleep' & $\mathrm{p}^{\mathrm{j}}$ & {$\left[\mathrm{sp}^{\mathrm{j}}\right] \mathrm{atit}^{\mathrm{j}}$} & 'to go crazy' \\
\hline & {$[\mathrm{fp}] \mathrm{ast}^{\mathrm{j}}$} & 'to fall into' & & {$\left[\mathrm{fp}^{\mathrm{j}}\right]$ atero } & 'five times' \\
\hline $\mathrm{t}$ & [st]ado & 'herd' & $\mathrm{t}^{\mathrm{j}}$ & {$\left[\mathrm{st}^{\mathrm{j}}\right] \mathrm{ag}$} & 'flag' \\
\hline & {$[\mathrm{ft}$ ]oroj } & 'second' & & {$\left[\mathrm{ft}^{\mathrm{j}}\right] \mathrm{ër}$} & 'rubbed in' \\
\hline $\mathrm{k}$ & {$[\mathrm{sk}] \mathrm{ot}$} & 'cattle' & $\mathrm{k}^{\mathrm{j}}$ & {$\left[\mathrm{tk}^{\mathrm{j}}\right] \mathrm{e} \mathrm{t}$} & 'he/she weaves' \\
\hline 1 & [pl]avat & 'to swim' & $1^{j}$ & {$\left[\mathrm{pl}^{\mathrm{j}}\right]$ aska } & 'dance' \\
\hline $\mathrm{r}$ & [pr]avyj & 'right' & $\mathrm{r}^{\mathrm{j}}$ & {$\left[\mathrm{pr}^{\mathrm{j}}\right] \mathrm{amo}$} & 'straight' \\
\hline $\mathrm{n}$ & {$[\mathrm{kn}] \mathrm{ut}$} & 'whip' & $\mathrm{n}^{\mathrm{j}}$ & {$\left[\mathrm{kn}^{\mathrm{j}}\right] \mathrm{az}{ }^{\mathrm{j}}$} & 'prince' \\
\hline
\end{tabular}

(35) no palatalized $\mathrm{C}_{1}$ in Russian word-initial onsets (Kochetov 1999: 193)

$$
\begin{array}{lllll}
\mathrm{p} & {[\mathrm{pr}] \mathrm{avyj}} & \text { 'right' } & * \mathrm{p}^{\mathrm{j}} & *\left[\mathrm{p}^{\mathrm{j}} \mathrm{r}\right], *\left[\mathrm{p}^{\mathrm{j}} \mathrm{r}^{\mathrm{j}}\right] \\
& {[\mathrm{pl}] \mathrm{avat}} & \text { 'to swim' } & & *\left[\mathrm{p}^{\mathrm{j} l}\right], *\left[\mathrm{p}^{\mathrm{j}} \mathrm{j}^{\mathrm{j}}\right] \\
\mathrm{k} & {[\mathrm{kl}] \mathrm{ast}^{\mathrm{j}}} & \text { 'to put down' } & * \mathrm{k}^{\mathrm{j}} & *\left[\mathrm{k}^{\mathrm{j}} \mathrm{l}\right], *\left[\mathrm{k}^{\mathrm{j}} \mathrm{j}^{\mathrm{j}}\right] \\
\mathrm{t} & {[\mathrm{tr}] \mathrm{ud}} & \text { 'labour' } & * \mathrm{t}^{\mathrm{j}} & *\left[\mathrm{t}^{\mathrm{j}} \mathrm{r}\right], *\left[\mathrm{t}^{\mathrm{j}} \mathrm{r}^{\mathrm{j}}\right]
\end{array}
$$

We conclude from this that complex onsets in Russian are either plain (pl) or palatalized

\begin{tabular}{|c|c|c|}
\hline & plain & palatalized \\
\hline stop + 1: & $\begin{array}{lllll}\mathrm{pl} & \mathrm{bl} & \mathrm{dl} & \mathrm{kl} & \mathrm{gl}\end{array}$ & $\mathrm{pl}^{\mathrm{j}} \quad \mathrm{bl}^{\mathrm{j}} \quad \mathrm{dl}^{\mathrm{j}} \quad \mathrm{kl}^{\mathrm{j}} \quad \mathrm{gl}^{\mathrm{j}}$ \\
\hline stop + r: & $\mathrm{pr}$ br $\operatorname{tr} \mathrm{dr} \mathrm{kr} \quad \mathrm{gr}$ & $\begin{array}{llllll}\operatorname{pr}^{\mathrm{j}} & \mathrm{br}^{\mathrm{j}} & \operatorname{tr}^{\mathrm{j}} & \mathrm{dr}^{\mathrm{j}} & \mathrm{kr}^{\mathrm{j}} & \mathrm{gr}^{\mathrm{j}}\end{array}$ \\
\hline stop + N: & pn $\mathrm{dn} \mathrm{kn}$ & $\mathrm{pn}^{\mathrm{j}} \quad \mathrm{d} n^{\mathrm{j}} \quad \mathrm{kn}^{\mathrm{j}} \quad \mathrm{tm}^{\mathrm{j}}$ \\
\hline $\mathrm{C}+$ fricative & $\mathrm{dv}, \mathrm{sf}$ & $d v^{j} \quad s f^{j}$ \\
\hline fricative $+\mathrm{C}$ : & $\mathrm{fp} \quad \mathrm{ft} \quad \mathrm{sp} \quad \mathrm{st} \quad \mathrm{zd}$ sk $\mathrm{sl}$ & $\begin{array}{lllllll}\mathrm{fp}^{\mathrm{j}} & \mathrm{ft}^{\mathrm{j}} & \mathrm{sp}^{\mathrm{j}} & \mathrm{st}^{\mathrm{j}} & \mathrm{zd}^{\mathrm{j}} & \mathrm{sk}^{\mathrm{j}} & \mathrm{sl}^{\mathrm{j}}\end{array}$ \\
\hline s + stop + liquid: & spr str & $\operatorname{spr}^{\mathrm{j}} \quad \operatorname{str}^{\mathrm{j}}$ \\
\hline
\end{tabular}
$\left(\mathrm{pl}^{\mathrm{j}}\right)$, with 'late palatalization' being the norm, as we see in the non-exhaustive but representative set of clusters in (36).

(36) CC onsets in Russian (Kochetov 1999: 192-194; Chew 2003: 358ff)

Irish and Russian are less different than (33) and (36) would suggest because palatalization in Russian extends phonetically to the first consonant in many of the clusters above. The factors supporting (or inhibiting) so-called 'assimilation' are complex, involving 
phonological and sociolinguistic factors, and also some amount of free variation. According to Timberlake,

Whether palatalization extends over both consonants or begins in the middle of the cluster depends on the extend to which the two consonants are articulatorily linked in other respects. The more linked the two consonants, the more likely it is that palatalization will extend throughout the cluster. There is variation, and the trend is very much towards losing assimilation. (Timberlake 2004:61)

As far as 'articulatory linkage' is concerned, the generalization seems to be that coronal clusters (save liquids) are usually realized with palatalization throughout (i.e. $\mathrm{d}^{\mathrm{j}} n^{\mathrm{j}}, \mathrm{s}^{\mathrm{j}} \mathrm{t}^{\mathrm{j}}, \mathrm{z}^{\mathrm{j}} \mathrm{d}^{\mathrm{j}}$ etc.), while clusters of coronal + labial $\left(\mathrm{s}^{\mathrm{j}} \mathrm{p}^{\mathrm{j}}, \mathrm{d}^{\mathrm{j}} \mathrm{v}^{\mathrm{j}}, \mathrm{s}^{\mathrm{j}} \mathrm{f}^{\mathrm{j}}\right)$ are less commonly realized with palatalization throughout (see Barry 1992, Houtzagers 2003, and Kochetov 1999, 2005 for further discussion). Again, the crucial point is that onsets in Russian use neither the position nor the extension of palatalization in distinctive ways, i.e. $\left[\mathrm{st}^{\mathrm{j}}\right]$ and $\left[\mathrm{s}^{\mathrm{j}} \mathrm{t}^{\mathrm{j}}\right]$ are just phonetic variants of a palatalized complex onset $(\mathrm{st})^{\mathrm{j}}$.

Complex codas in Russian show an even more varied picture, though generally [r] seems to shun palatalization while other coronals attract it. But the timing of palatalization is not distinctive in these clusters either, i.e. Russian has words like ska[1 $\left.{ }^{\mathrm{j}} \mathrm{p}\right]$ 'scalp', but neither $*_{\text {ska }}\left[1 p^{\mathrm{j}}\right]$ nor ${ }^{*} \mathrm{ska}\left[\mathrm{l}^{\mathrm{j}} \mathrm{p}^{\mathrm{j}}\right]$; and while it has words like sko[rp $\left.\mathrm{p}^{\mathrm{j}}\right]$ 'grief', it doesn't have ${ }^{*} \mathrm{sko}\left[\mathrm{r}^{\mathrm{j}} \mathrm{p}\right]$ or ${ }^{*} \operatorname{sko}\left[\mathrm{r}^{\mathrm{j}} \mathrm{p}^{\mathrm{j}}\right]$. The list in (37) is again representative but not exhaustive (the parenthesized superscript $\mathrm{j}$ in the final row refers to palatalization from assimilation).

(37) Final CC codas in Russian (Kochetov 1999: 195-197; Chew 2003: 358ff)

\begin{tabular}{|c|c|c|}
\hline & plain & palatalized \\
\hline $1+\mathrm{C}:$ & lp $\quad$ it $\quad 1 \mathrm{k}$ & $1^{\mathrm{j} p} \quad \mathrm{j}^{\mathrm{j} t} \quad \mathrm{l}^{\mathrm{j}} \mathrm{k}$ \\
\hline $\mathrm{r}+\mathrm{C}$ : & $\mathrm{rp} \quad \mathrm{rm} \quad \mathrm{rt} \quad \mathrm{rk}$ & $\mathrm{rp}^{\mathrm{j}} \quad \mathrm{rm}^{\mathrm{j}} \quad \mathrm{rt}^{\mathrm{j}}$ \\
\hline $\mathrm{N}+$ stop: & $\mathrm{mp} \quad \mathrm{nt} \mathrm{nk}$ & - \\
\hline stop + stop & pt kt & $\mathrm{t}^{\mathrm{j}} \mathrm{p}$ \\
\hline fricative $+C$ & $\begin{array}{lllll} & \mathrm{sp} & \mathrm{st} & \mathrm{ft} & \mathrm{fk}\end{array}$ & $s^{j} p \quad s^{(j) t^{j}} \quad f^{j}$ \\
\hline
\end{tabular}

Summarizing, then, where palatalization occurs within a complex onset or coda (pre vs. post) is not generally contrastive in Russian. More generally, pre- vs. post-palatalization, pre- vs. post-velarization, and pre- vs. post-labialization aren't contrastive in any language. We consider a few problematic words in Russian below, but they should not seriously detract from the bigger picture. 


\section{No segment/cluster contrasts within a margin}

Glides have always played two closely related roles in phonology, serving both as segments $[j$, u, $\beta, w, ~ y]$ and as secondary properties of other segments in the form of palatalization, velarization, labialization, and so on: $\left[\mathrm{p}^{\mathrm{j}}, \mathrm{p}^{\mathrm{y}}, \mathrm{p}^{\mathrm{\beta}}, \mathrm{p}^{\mathrm{w}}, \mathrm{p}^{\mathrm{y}}\right]$. With but a few exceptions examined below, the difference between a $\mathrm{Cj}$ cluster and a palatalized $\mathrm{C}^{\mathrm{j}}$ has never been claimed to be contrastive.

Palatalized or (labio-)velarized consonants are often analysed as separate series $\left[\mathrm{p}^{\mathrm{j}}\right.$, $\left.\mathrm{p}^{\mathrm{w}}\right]$ or as clusters $[\mathrm{pj}, \mathrm{pw}]$ on the basis of phonological economy or parsimony. If a language has the sounds $\left[p, j, p^{j}\right]$ the latter is often analyzed as a cluster [pj] rather than a palatalized consonant $\left[p^{j}\right]$, thereby simplifying the system of phonemes (e.g., Hockett 1955). Conversely, if a language seems to have palatalization, one usually assumes that $\mathrm{Cj}$ clusters are banned. But such considerations are not without costs. A cluster analysis [pj] usually complicates the syllable structure to simplify the phoneme inventory, just as a palatalization analysis $\left[\mathrm{p}^{\mathrm{j}}\right]$ complicates the phoneme inventory to simplify the syllable structure. Feature economy (Clements 2001, 2003) predicts that any language with both [p] and [j] would prefer $\left[p^{j}\right]$ (which drives up the numbers of segments per feature, increasing economy) to a cluster [pj] (which drives down the number of segments per feature, decreasing economy). Considerations of syllable complexity point in the same direction, since $\left[\mathrm{p}^{\mathrm{j}}\right]$ is a simple onset while [pj] is complex.

But the crucial test for ' $\mathrm{Cj}$ clusters' and ' $\mathrm{C}^{\mathrm{j}}$ segments', or $\mathrm{Cu}$ and $\mathrm{C}^{\mathrm{y}}$, is contrast. Theories of phonology that include both $\mathrm{Cj}$ and $\mathrm{C}^{\mathrm{j}}$ (or $\mathrm{Cu}$ and $\mathrm{C}^{\mathrm{y}}$, etc.) tacitly assume the two will contrast in some language. Except for a handful of words from Russian $(\leq 5)$ we have found no language with such a contrast and therefore doubt that the issue of clusters vs. vocalized single consonants can be substantiated empirically.

\section{Problematic contrasts in Russian}

Before closing our discussion of existing and non-existing vocalic contrasts in onsets and codas, we would like to comment on a number of words in Russian which seem to violate our proposals in (3-4). Russian is of course well known for it's complex word-initial onsets, - [mgla] 'haze', [tknut $\left.{ }^{\mathrm{j}}\right]$ 'poke', or [ $\left.\mathrm{vzgl}^{\mathrm{j}} \mathrm{ad}\right]$ 'look' - and since some of the problematic words involve these, we will begin by considering them first. Noting that word-internal onsets are well-behaved in terms of sonority sequencing, Yearley proposes that certain word-initial consonants fall outside of the onset proper and are licensed outside of the syllable proper: 
The lack of concern for sonority sequencing on the part of these peripheral elements strongly suggests that they are in fact external to the syllable formed by immediately subsequent segmental material. Given that despite being syllableexternal they are obviously still parsed (since they are audible components of the optimal form), it seems plausible that they are parsed directly by the Prosodic Word. (Yearley 1995: 546)

The sounds in [mgla] 'haze', for instance, are prosodically licensed as in (36) for Yearley:

(38) Extrasyllabic consonant in [mgla] 'haze'

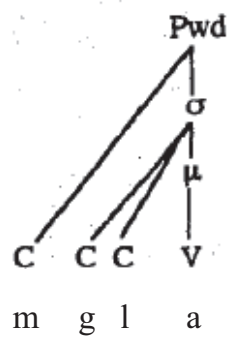

With the $[\mathrm{m}]$ out of the way, the [gl] forms a normal onset to the syllable, rising in sonority. This bears on our proposals in (2-4), of course, because of the status of [m] with respect to the onset; if Yearley's proposal is correct, (2-4) should not apply to consonants that are licensed directly by the Pwd, as (2-4) apply only to syllable margins proper. Consonants that fall outside of the syllable are not subject to (2-4).

There are no systematic exceptions to our (3) in Russian or in any other language we know of, but we do find in Russian a handful of exceptional lexical items that are prima facie violations. Consider our (3), repeated here as (39).

$(39)=(3)$ No pre/post contrasts within a syllable margin

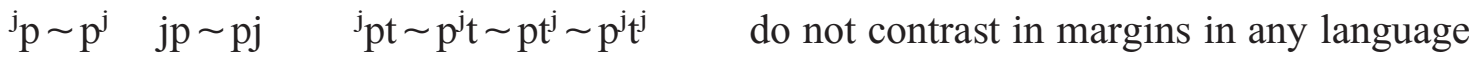

$$
\begin{aligned}
& { }^{\mathrm{x}} \mathrm{p} \sim \mathrm{p}^{\mathrm{\gamma}} \quad \text { uр } \sim \mathrm{pщ} \quad{ }^{\mathrm{\gamma}} \mathrm{pt} \sim \mathrm{p}^{\mathrm{\gamma} t} \sim \mathrm{pt}^{\mathrm{\gamma}} \sim \mathrm{p}^{\mathrm{\gamma}} \mathrm{t}^{\mathrm{\gamma}} \quad \text { do not contrast in margins in any language }
\end{aligned}
$$

If the laterals in the words in (40) are part of the syllable onset, they provide counterexamples to our (3). The first two parts of (3) are left intact $\left({ }^{j} p \sim p^{j}\right.$ and $\left.j p \sim p j\right)$, but the third $\left({ }^{\mathrm{j}} \mathrm{pt} \sim \mathrm{p}^{\mathrm{j}} \mathrm{t} \sim \mathrm{pt}^{\mathrm{j}} \sim \mathrm{p}^{\mathrm{j} \mathrm{t}^{\mathrm{j}}}\right)$ is violated if the palatalization in a complex onset can be either early $\left(l^{\mathrm{j}} \mathrm{d}\right)$ or late $\left(1 \mathrm{~b}^{\mathrm{j}}\right)$.

$$
\begin{array}{ll}
\mathrm{l}^{\mathrm{j}} \mathrm{da} & \text { 'ice (gen)' } \\
\mathrm{lb}^{\mathrm{j} e} & \text { 'forehead (prep)' }
\end{array}
$$

But if the laterals in (40) are extrasyllabic (41), as required by sonority sequencing, these words are no longer counterexamples to our claim and Yearley's proposal for extrasyllabic consonants saves the day. 
(41) Exceptional initial clusters and extrasyllabicity

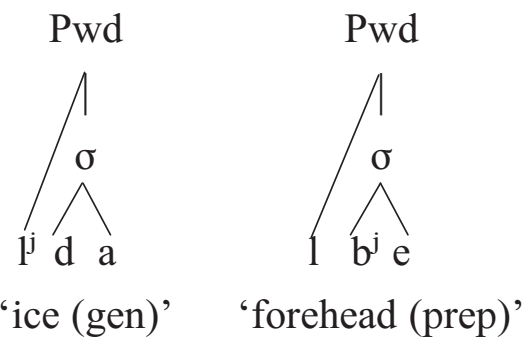

This doesn't solve all of the problems, though, since not all affronts to (3) involve obvious sonority sequencing violations. This is the case for the words in (42), which seem to contrast where in the onset the palatalization occurs: early $\left[\mathrm{t}^{\mathrm{j}} \mathrm{m}\right]$, late $\left[\mathrm{tm}^{\mathrm{j}}\right]$, or both $\left[\mathrm{t}^{\mathrm{j}} \mathrm{m}^{\mathrm{j}}\right]$.

(42) $\mathrm{tm}^{\mathrm{j}}$ in 'caraway'

$$
\begin{array}{ll}
\mathrm{t}^{\mathrm{j}} \mathrm{ma} & \text { 'darkness' } \\
\mathrm{t}^{\mathrm{j}} \mathrm{m}^{\mathrm{j}} \mathrm{e} & \text { 'darkness (loc.sg.) }
\end{array}
$$

The phonologically regular case is [ $\mathrm{tm}^{\mathrm{j}} \mathrm{in}$ ] 'caraway' (see (36)), with [ $\mathrm{t}^{\mathrm{j}} \mathrm{ma}$ ) and $\left[\mathrm{t}^{\mathrm{j}} \mathrm{m}^{\mathrm{j}} \mathrm{e}\right.$ ] requiring explanation. We claim that the initial [ $\left.\mathrm{t}^{\mathrm{j}}\right]$ in these words, too, is extrametrical, because the cluster is separated underlyingly by yer. ${ }^{17}$ The analysis relies on Yearley again, who argues that such initial clusters be represented as in (41), even if they do not involve sonority sequencing violations (Yearley 1995: 560-67). Removing the initial $\left.{ }^{[\mathrm{t}}\right]$ from the onset in these words takes away the violation of (3), as shown in (43).

(43) Regular $\left[\mathrm{tm}^{\mathrm{j}}\right]$ and exceptional initial clusters

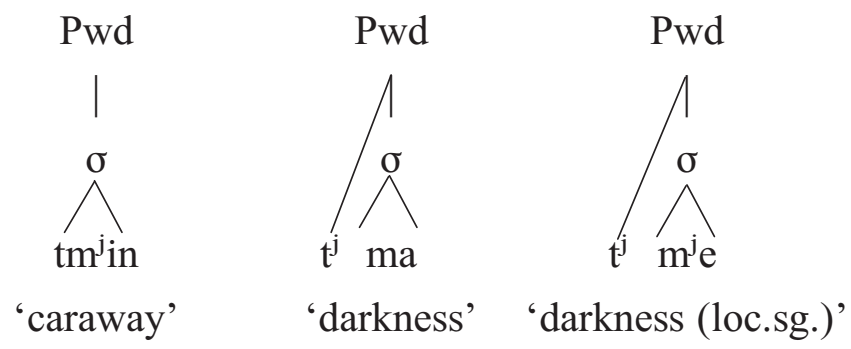

We found one more case of an apparent timing contrast at the other end of the word. As we show in the left column of (44), palatalization is regularly realized early in [1t] codas, regardless of whether the final consonant is underlyingly /t/ (a) or /d/ (b). ${ }^{18}$ Kochetov (1999:196) provides two exceptional forms (and we found no others), one with late palatalization $\left[1 t^{\mathrm{j}}\right]$ (proželt $\left.\mathrm{t}^{\mathrm{j}}\right)$, one with palatalization throughout $\left[1^{\mathrm{j}^{\mathrm{j}}} \mathrm{t}^{\mathrm{j}}\right]\left(\mathrm{s}^{\mathrm{j}} \mathrm{l}^{\mathrm{j} \mathrm{t}^{\mathrm{j}}}\right)$.

\footnotetext{
17 Cf. [t'im'no] 'dark'.

18 Russian has final devoicing, and thus both clusters surface as $\left[\mathrm{j}^{\mathrm{j}} \mathrm{t}\right]$.
} 
(44) a. vol ${ }^{\mathrm{j} t} \quad$ 'volt'

proželt' 'yellow tint'

pul' 'desk'

kul ${ }^{\mathrm{j}} \mathrm{t} \quad$ 'cult'

$\mathrm{k}^{\mathrm{j}} \mathrm{el}^{\mathrm{j}} \mathrm{t} \quad$ 'Celt'

b. kobol't 'goblin'

$\mathrm{s}^{\mathrm{j}} \mathrm{el}^{\mathrm{j}} \mathrm{t}^{\mathrm{j}} \quad$ 'herring'

$\mathrm{g}^{\mathrm{j}} \mathrm{erol}^{\mathrm{j}} \mathrm{t} \quad$ 'herald'

skal' 'skald'

Coronals generally assimilate to following palatalized coronals in Russian, but this doesn't happen with liquids, allowing for near minimal pairs like those in (44). If the word-final consonants are all in the coda here, we again face violations of (3).

We assume that $\left.{ }^{[\mathrm{j}}\right]$ in these words, too, is extrametrical, again parallel to sonoritydriven-extrametricality in words like vnutr' 'inside'. Admittedly, however, we lack independent evidence for this claim as yet.

(45) Regular $\left[1^{\mathrm{j}} \mathrm{t}\right]$ and exceptional final clusters

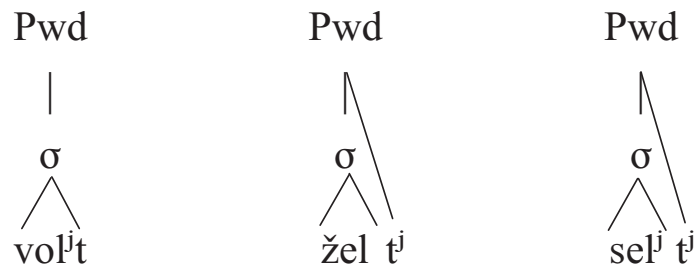

So far, the very serious counterexamples in (40), (42) and (44) have yielded to independently needed extrasyllabic analysis based on sonority and underlying yers.

This brings us to apparent violations of our claim in (4), repeated here as (46). $(46)=(4)$ No segment/cluster contrasts within a syllable margin

$$
\begin{array}{lll}
\mathrm{p}^{\mathrm{j}} \sim \mathrm{pj} & \mathrm{pt}^{\mathrm{j}} \sim \mathrm{ptj} & \text { do not contrast in margins in any language } \\
\mathrm{p}^{\mathrm{y}} \sim \mathrm{pu} & \mathrm{pt}^{\mathrm{y}} \sim \mathrm{ptu} & \text { do not contrast in margins in any language }
\end{array}
$$

Apparent counterexamples to (4) include the words in (47).
$p^{\mathrm{j} o t r}$ 'Peter'
liot 'ice (nom)'
pjot 'drinks'
$1^{\mathrm{j} j o t}$ 'pours'

Ladefoged \& Maddieson describe the acoustic difference of the first pair as follows:

In [ $\left.\mathrm{p}^{\mathrm{j}} \mathrm{otr}\right]$ 'Peter' the transition away from the palatal position, indicated by a falling

F2, begins immediately on consonantal release. In contrast, in [pjot] 'drinks' there

is a short steady state before the transition begins. (p. 364)

We assume that something similar holds for the second pair, which we take to be something closer to $\left[\mathrm{l}^{\mathrm{j} o t}\right]$ and $\left[\mathrm{1}^{\mathrm{j} j o t}\right]$, since palatalization is generally realized with sonorants rather than 
before or after them. Neither of these pairs involves sonority sequencing violations, and so neither can be reanalyzed with extrasyllabic consonants: $\left[\mathrm{p}^{j}\right]$ and $[\mathrm{pj}]$ are indistinguishable onsets for our approach, as are $\left[\mathrm{l}^{\mathrm{j}}\right]$ and $\left[\mathrm{j}^{\mathrm{j} j}\right]$ (and $[\mathrm{lj}]$ for that matter), since we take an onset to have just a single set of secondary vocalic features and take the difference between $\left[{ }^{j}\right]$ and [j] to be orthographic and not phonological or phonetic.

An unpublished study by Moldalieva (2012), however, suggests that the onsets in these words are not $\left[p^{\mathrm{j}}\right] \sim[\mathrm{pj}]$ and $\left[\mathrm{1}^{\mathrm{j}}\right] \sim\left[\mathrm{1}^{\mathrm{j} j}\right]$, but $\left[\mathrm{p}^{\mathrm{j}}\right] \sim[\mathrm{p}]$ and $\left[\mathrm{l}^{\mathrm{j}}\right] \sim\left[\mathrm{1}^{\mathrm{j}}\right]$ and that the lower case [j] in both cases resides in the nucleus rather than the onset. Moldalieva asked subjects to rank pairs of words in terms of how well they rhyme, to determine the syllabic affiliation of the medial glides. The result was three groups, words that don't rhyme, words whose rhyme is just OK, and words whose rhyme is excellent. An example of two words that don't rhyme is given in (48); it is bad presumably because the rhyme portion of each word is different $\left(\mathrm{ot} \sim \mathrm{os}^{\mathrm{j}}\right)$ and no subjects said they rhymed.

(48) $0 \%$ rhyme

$$
\mathrm{l}^{\mathrm{j}} \mathrm{ot} \sim \operatorname{los}^{\mathrm{j}} \quad \text { 'ice } \sim \text { elk' }
$$

This just shows that speakers knew what a rhyme was. At the other end of the scale were words that scored almost perfectly in terms of rhyme, 93\% 'excellent' responses (49).

(49) Excellent rhyme (93\%)

$$
\begin{array}{llll}
\mathrm{l}^{\mathrm{j} j o t} \sim \mathrm{p}^{\mathrm{j} j o t} & \text { 'pours } \sim \text { drinks' } & \mathrm{p}^{\mathrm{j} j o t} \sim \mathrm{b}^{\mathrm{j} j o t} & \text { 'drinks } \sim \text { hits' } \\
\mathrm{l}^{\mathrm{j} o t} \sim \mathrm{m}^{\mathrm{j}} \text { ot } & \text { 'ice } \sim \text { honey' } & \mathrm{l}^{\mathrm{j} \text { ot } \sim \mathrm{gn}^{\mathrm{j}} \text { ot }} & \text { 'ice } \sim \text { oppression' } \\
\mathrm{l}^{\mathrm{j} j o t} \sim \mathrm{b}^{\mathrm{j} j o t} & \text { 'pours } \sim \text { hits' } & \mathrm{l}^{\mathrm{j} j o t ~} \sim \mathrm{v}^{\mathrm{j} j o t} & \text { 'pours } \sim \text { twists' }
\end{array}
$$

These words should rhyme on any internally consistent account of where [j] and [j] go. Finally, there were words whose rhymes were deemed just ok (50).

(50) OK rhyme $(50 \%)$

$$
\begin{aligned}
& \mathrm{l}^{\mathrm{j} o t} \sim \mathrm{l}^{\mathrm{j} j o t} \quad \text { 'ice } \sim \text { pours' } \quad \text { pə' } \mathrm{l}^{\mathrm{j}} \mathrm{ot} \sim \text { pə' } \mathrm{l}^{\mathrm{j} j \mathrm{j} \text { ot }} \text { 'flight } \sim \text { will pour' } \\
& \mathrm{jel}^{\mathrm{j}} \sim \mathrm{el}^{\mathrm{j}} \quad \text { 'fir-tree } \sim \text { ale' } \text { jof } \sim \text { of 'hedgehog } \sim \text { city name' }
\end{aligned}
$$

The words in (50) should rhyme perfectly according to the usual assumption, that $\left.{ }^{j}\right]$ and $[j]$ are part of the syllable margin; they should not rhyme at all according to our proposal, that $\left.{ }^{j}\right]$ is part of the margin while [j] is part of the nucleus. So neither model straightforwardly captures the facts.

One way we see of understanding the $50 \%$ figure involves different ways that the participants might have understood rhyming: (i) identical material in the rhyme, (ii) identical material from the last sonority peak to the end of the syllable. According to our proposal here, with $\left.{ }^{\mathrm{j}}\right]$ in the margin and $[\mathrm{j}]$ in the nucleus, speakers' instuitions should be split: (i) 
would make the rhymes bad (eg, ot jot for 'ice pours') and (ii) would make the rhymes good (ot $\sim$ ot for 'ice $\sim$ pours'). According to the standard proposal, with $\left[{ }^{j}\right]$ and $[j]$ in the margin, speakers' intuitions should be unanimous: (i) would make the rhymes good (ot $\sim$ ot for 'ice $\sim$ pours') and (ii) would as well (ot $\sim$ ot for 'ice $\sim$ pours'), since the last sonority peak would be the mid vowel in both cases. If our reasoning here is correct, our proposal can be made compatible with the data, but the traditional proposal cannot be. More work clearly needs to be done, but we take Moldalieva's results as promising and as better support for our proposal than for the standard approach.

If we are correct, the syllabic affiliation of $\left.{ }^{\mathrm{j}}\right]$ is the margin while that of $[\mathrm{j}]$ is the nucleus (51).

(51) Monophthong vs. diphthong
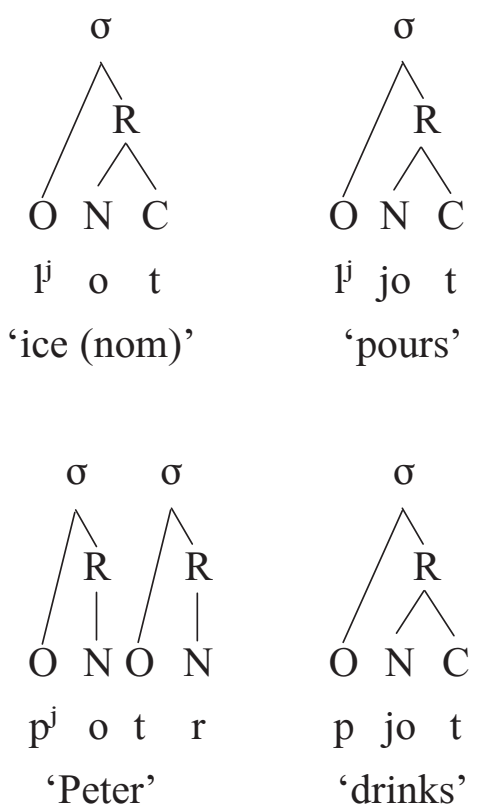

Recall Ladefoged \& Maddieson's description of the acoustic difference: in 'Peter' the transition away from the palatal begins immediately, but in 'drinks' there is a short stead state before the transition to the vowel. (51) would account for this by having the palatal in the onset and non-moraic for 'Peter' and in the nucleus and moraic for 'drinks', a plausible distinction.

Finally, we should mention an interesting near-minimal triple that Padgett (2008, footnoe 2) raises (52).

(52) $\mathrm{p}^{\mathrm{j}} \mathrm{ast}^{\mathrm{j}} \quad$ 'metacarpus'

'pjan.stvə 'drunkenness'

pi.'a.str 'piaster' 
Padgett takes this as evidence for a lexical distinction between [ $\left.{ }^{\mathrm{j}}\right],[\mathrm{j}]$ and [i], which it may well be. But our proposal here offers a different possibility, in which the distinction is palatalization in the onset $\left(\mathrm{p}^{\mathrm{j}} \mathrm{as}^{\mathrm{j}}\right)$, palatalization in a compex nucleus (pjan), and palatalization in a simple nucleus (pi).

\section{Assimilation}

Up to this point we have looked at attested and unattested contrasts in the languages of the world. We turn now to assimilation, to how palatalization, rounding, and backness spread when morphemes are concatenated. Phonological processes like these show that (a) vocalizations apply to margins as a whole, rather than to individual segments, and (b) Vfeatures are independent of $\mathrm{C}$-features. Both generalizations support the prosodic approach we advocate here.

\subsection{Assimilation across syllables}

As far as we have been able to find, vocalic neutralization and assimilation across subsyllabic constituents (from a coda to a preceding onset) apply to all consonants within the respective domains. Clear data come from Lithuanian, Irish, and Marshallese, to which we now turn.

Lithuanian (Ambrazas 1997) contrasts plain (velarized) and palatalized simple and complex onsets, the latter palatalized throughout (53). ${ }^{19}$

(53) Plain vs. palatalized margins in Lithuanian (Ambrazas 1997: 36-39)

\begin{tabular}{llll} 
Plain & \multicolumn{3}{c}{ Palatalized } \\
{$[\mathrm{k}]$ ùrti } & 'to create' & {$\left[\mathrm{k}^{\mathrm{j}}\right]$ ùrti } & 'to get holes' \\
{$[\mathrm{s}]$ ùsti } & 'to grow scabby' & {$\left[\mathrm{s}^{\mathrm{j}}\right]$ ùsti } & 'to grow angry' \\
{$[$ spr $]$ ãgilas } & 'flail' & {$\left[\mathrm{s}^{\mathrm{j}} \mathrm{p}^{\mathrm{j}} \mathrm{r}^{\mathrm{j}}\right]$ ęsti } & 'to decide'
\end{tabular}

Word-final codas are neutralized towards the plain series (54).

(54) Word-final neutralization in Lithuanian (Ambrazas 1997: 36-39)

\begin{tabular}{|c|c|c|c|}
\hline Palatalized & & Plain & \\
\hline $\operatorname{gu}\left[\mathrm{j}^{\mathrm{j}} \mathrm{s}^{\mathrm{j}}\right] \mathrm{u}$ & '(I) will lie (down)' & $\mathrm{gu}[1 \mathrm{t}]$ & 'to lie (down)' (clipped inf.) \\
\hline Švi $\left[1^{j} p^{j} t^{j}\right] i$ & 'to whistle' & Švi[lpt] & 'to whistle' (clipped inf.) \\
\hline
\end{tabular}

19 Before back vowels, only. Front vowels are always preceded by palatalized consonants/clusters. 
Medial clusters that arise when morphemes are brought together must agree in palatality, via regressive assimilation from morpheme-initial consonants or front vowels (55). ${ }^{20}$

(55) Palatal agreement in Lithuanian (Ambrazas 1997: 36-39)

\begin{tabular}{|c|c|c|c|}
\hline Plain & & Palataliz & \\
\hline nè $\left[\int t\right] u$ & '(he) would carry' & $\operatorname{ne}\left[\int^{\mathrm{j}} \mathrm{t}^{\mathrm{j}}\right] \mathrm{i}$ & 'to carry' \\
\hline $\mathrm{i}[1$ 'st $] \mathrm{a}$ & '(he) grows tired' & $i\left[\mathrm{j}^{\mathrm{j}} \mathrm{S}^{\mathrm{j}} \mathrm{t}^{\mathrm{j}}\right] \mathrm{i}$ & 'to grow tired \\
\hline
\end{tabular}

The data in (53) - (55) show that secondary vocalic articulations affect onsets and codas as a whole in Lithuanian: onsets are plain or palatalized (53), word-final codas lose palatality (54), and word-medial codas agree in palatality with following onsets (55). Moreover, neutralization and agreement of secondary vocalic articulations act independently of 'primary' consonantal place features: consonants neither neutralize word-finally nor do they assimilate word-medially.

Palatal agreement and C-Place assimilation in Irish $^{21}$, however, make clear that vocalic and consonantal place features must be altogether independent because in this language coda nasals can assimilate to a following dorsal without a change in vocalic palatality. In $(56 \mathrm{a}, \mathrm{b})$ palatalized codas $/ \mathrm{n}^{\mathrm{j}} /$ turn into $\left[\mathrm{n}^{\mathrm{j}}\right]$ before plain velar stops, while in (c, d) plain codas $/ \mathrm{n} /$ turns into plain [ $\mathrm{n}$ ] before palatalized velar stops. Velar stops thus transfer their C-Place features, but not their V-Place features, to a preceding nasal. These facts are difficult to reconcile with feature geometrical views that assume V-Place as a dependent of C-Place (Sagey 1986, among others).

(56) Nasal place assimilation without palatalization in Irish (Ní Chiosáin 1994: 96)

$$
\begin{aligned}
& n^{\mathrm{j}} \rightarrow \mathrm{n}^{\mathrm{j}} \quad \text { a. } \mathrm{s}^{\mathrm{j}} \mathrm{in}^{\mathrm{j}} \\
& \text { DEMONSTRATIVE }
\end{aligned}
$$

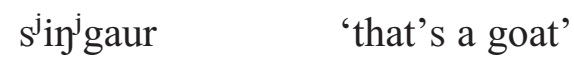

$$
\begin{aligned}
& \text { b. ji:nhin } \\
& \text { jinhip gir'əsə 'I would do without it' } \\
& \mathrm{n} \rightarrow \mathrm{y} \quad \text { c. saispən 'a saucepan' } \\
& \text { sa:spəng }{ }^{j} \text { al 'a bright saucepan' } \\
& \text { d. diilən 'a diary' }
\end{aligned}
$$

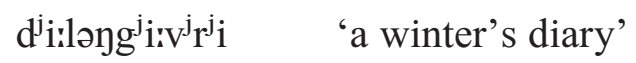

20 With the apparent exception of velar stops [k, g], described as "usually not palatalized, but [...] 'transparent'

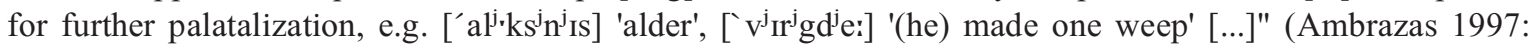
37). [Transcriptions adapted to IPA. ['] and [] indicate acute and circumflex accent, respectively.]

21 Word-internal palatal agreement in Irish is parallel to Lithuanian. Notice, though, that there is no final neutralization in Irish, e.g. $\mathrm{sa}\left[\mathrm{n}^{\mathrm{j}} \mathrm{t}^{\mathrm{j}}\right]$ 'saint'. 
Our prosodic model predicts of course that V-place and C-place features can act independently. But we also get the prosodic effects of neutralization and assimilation for free, unlike models which assign such features directly to a segment or root node.

(57) Autosegmental representations of neutralization and assimilations under Prosodic Licensing of vocalic features

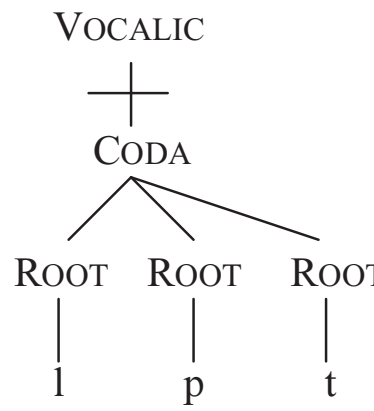

$/(1 \mathrm{pt})^{\mathrm{j} /} \rightarrow[\mathrm{lpt}]$

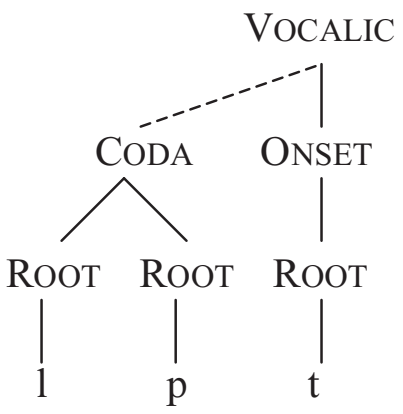

$/ \mathrm{lp} \cdot(\mathrm{t})^{\mathrm{j} /} \rightarrow\left[\mathrm{l}^{\mathrm{j}} \mathrm{p}^{\mathrm{j}} \cdot \mathrm{t}^{\mathrm{j}}\right]$

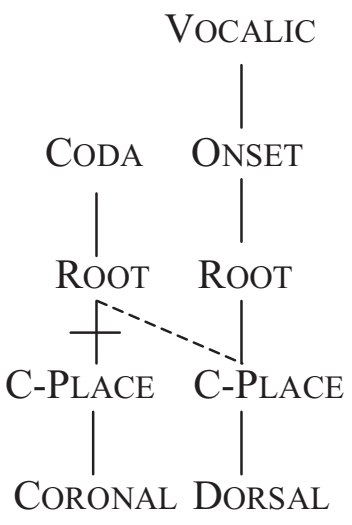

$/ \mathrm{n} \cdot(\mathrm{k})^{\mathrm{j} /} \rightarrow\left[\mathrm{y} \cdot \mathrm{k}^{\mathrm{j}}\right]$

Marshallese illustrates a case where both C-Place and V-Place features require agreement across syllables, but violations are resolved in different ways: non-homorganic consonant clusters are always fixed by vowel epenthesis (57a), but non-homorganic vocalic articulations generally induce regressive assimilation (57b).

With the exception of certain identical and homorganic consonants, all full consonants juxtaposed by syntactic or morphological processes are separated by excrescent vowels of reduced and obscure quality which (insofar as it is determinate) can be predicted from the consonants and neigh-boring full vowels. (Bender 1968: 22)

(58) epenthesis vs. vocalic assimilation in Marshallese (Bender 1968: 22, 27)
a. $\quad / t^{\mathrm{j}} \partial \mathrm{r}^{\mathrm{w}} \mathrm{b}^{\mathrm{w}} \mathrm{a}^{\mathrm{j} /}$
$\left[\mathrm{t}^{\mathrm{j}} \mathrm{er}^{\mathrm{w}} \partial \mathrm{b}^{\mathrm{w}} \mathrm{a} \mathrm{l}^{\mathrm{j}}\right]$
'work'
$/ \mathrm{r}^{\mathrm{j}} \mathrm{ap}^{\mathrm{j}} \underline{\mathrm{i}}^{\mathrm{j}} \mathrm{p}^{\mathrm{j}} \mathrm{i}^{\mathrm{j}} /$
$\left[\mathrm{r}^{\mathrm{j}} \varepsilon \mathrm{p}^{\mathrm{j}} \mathrm{l}^{\mathrm{j}} \mathrm{ip}^{\mathrm{j}} \mathrm{il}^{\mathrm{j}}\right]$
'to roll (intr.)'
$/ \mathrm{m}^{\mathrm{w}}$ akm ${ }^{\mathrm{w}} \mathrm{ik} /$
[m ${ }^{\mathrm{wo}} \mathrm{akim}^{\mathrm{wu} \mathrm{ik}}$ ]
'arrowroot'

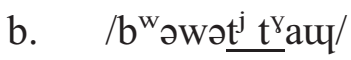

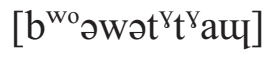
'which boat?'
/.. $\mathrm{n}^{\mathrm{j}} \mathrm{t}^{\mathrm{x}} . . /$
$\left[n^{\mathrm{Y}} \mathrm{t}^{\mathrm{Y}}\right]$
(no example)

\subsection{Assimilation within syllables}

Consonants and glides often start out as independent entities but end up in a single onset or coda in the course of morphophonological processes. Such cases typically raise the question of whether the output of concatenation should be treated as a cluster [pj] or as a single 
consonant $\left[\mathrm{p}^{\mathrm{j}}\right]$. As should be clear by now, such a question is moot from the perspective of prosodic licensing because the two are taken to be indistinguishable.

Vowel-glide alternations, as in French (59) and Kihehe (60) are the most familiar examples of this sort. In both languages we find high vowels becoming glides when a following vowel forces them into the onset:

(59) Vowel-glide alternations in French (Kaye \& Lowenstamm 1984)

$\begin{array}{llll}\text { li } & \text { 'tie-3.sg.' } & \text { lje } & \text { 'tie-inf' } \\ \text { lu } & \text { 'rent-3.sg.' } & \text { lwe } & \text { 'rent-inf' } \\ \text { ty } & \text { 'kill-3.sg.' } & \text { tye } & \text { 'kill-inf' }\end{array}$

(60) Vowel-glide alternations in Kihehe (Odden \& Odden 1999)

$\begin{array}{llll}\text { kú-haáta } & \text { 'to be fermenting' } & \text { kw-áala } & \text { 'to open palms' } \\ \text { li-telekwa } & \text { 'it (cl. 5) will be cooked' } & \text { lj-eeheéla } & \text { 'it (cl. 5) will breath' } \\ \text { i-lúma } & \text { 'it (cl. 9) will bite' } & \text { j-uúsa } & \text { 'it (cl. 9) will come' }\end{array}$

'Floating' vocalic morphemes like [round] in Chaha or [front] in Harari (Leslau 1958) present a second source for consonants and vowels joined under a single syllable margin. ${ }^{22}$ In Chaha, a 3rd singular masculine object is marked by labialization of the last 'labializable' stem consonant. ${ }^{23}$ As can be seen from the examples below, labialization is treated as a secondary feature $\left({ }^{w}\right)$ of the respective consonants in our source.

(61) Labialization in Chaha (McCarthy 1983:179)

without object with $3^{\text {rd }} \mathrm{m}$. sg. object

\begin{tabular}{|c|c|c|}
\hline a. dænæg & dænæg $^{\mathrm{W}}$ & 'hit' \\
\hline nædæf & nædæf ${ }^{w}$ & 'sting' \\
\hline nækæb & nækæb $^{\mathrm{w}}$ & 'find' \\
\hline b. nækæs & næk ${ }^{\mathrm{w}} æ s$ & 'bite' \\
\hline kæfæt & $\mathrm{kæf}^{\mathrm{w}} æ \mathrm{t}$ & 'open' \\
\hline bækær & $\mathrm{bæk}^{\mathrm{w}} æ \mathrm{r}$ & 'lack' \\
\hline c. qætær & $\mathrm{q}^{\mathrm{w}} æ t æ r$ & 'kill' \\
\hline mæsær & $\mathrm{m}^{\mathrm{w}}$ æsær & 'seem' \\
\hline$m æ k^{j} æ r$ & $\mathrm{~m}^{\mathrm{w}} æ \mathrm{k}^{\mathrm{j}} æ r$ & 'burn' \\
\hline d. sædæd & sædæd & 'chase' \\
\hline
\end{tabular}

22 See Akinlabi (1996) for more examples and formal analysis.

23 Chaha has labialized velars and labials, but no labialized coronals. 
Zoque (Wonderly 1951) presents another case of featural affixation. In this language, 3.sg.possessive is marked by palatalizing the first consonant (62). Unlike Chaha above, every consonant in Zoque has a palatalized counterpart.

(62) Zoque featural affixation (Wonderly 1951)

$\begin{array}{llll}\text { [pata }] & \text { 'mat' } & {\left[\mathrm{p}^{\mathrm{j} a} \mathrm{ata}\right]} & \text { 'his mat' } \\ {[\text { kama }]} & \text { 'cornfield' } & {\left[\mathrm{k}^{\mathrm{j} a} \mathrm{ma}\right]} & \text { 'his cornfield' } \\ {[\mathrm{faha}]} & \text { 'belt' } & {\left[\mathrm{f}^{\mathrm{j}} \mathrm{a} . \mathrm{ha}\right]} & \text { 'his belt } \\ {[\mathrm{s} \Lambda \mathrm{k}]} & \text { 'beans' } & {\left[\int \Lambda \mathrm{k}\right]} & \text { 'his beans' }\end{array}$

However, Zoque palatalization has a wider distribution, for it also occurs with affixes that are bigger than just palatalization (63).

(63) Zoque metathesis or coalescence

$\begin{array}{lll}\text { poj-pa } & {\left[\text { po.p } \mathrm{p}^{\mathrm{j} a}\right]} & \text { 'he runs' } \\ \text { tsaj-k } \Lambda \text { si } & {\left[\text { tsa.k }^{\mathrm{j}} \Lambda \mathrm{si}\right]} & \text { 'on the wine' } \\ \text { kuj-m } \Lambda \mathrm{j} & {\left[\mathrm{ku} \cdot \mathrm{m}^{\mathrm{j}} \Lambda \mathrm{j}\right]} & \text { 'a week hence' } \\ \text { takaj-Pah-u } & {\left[\text { ta.ka. }{ }^{\mathrm{j}} \mathrm{a} \cdot \mathrm{hu}\right]} & \text { 'it becomes bitter' }\end{array}$

Wonderly treats palatalization in Zoque as metathesis, such that j-pata becomes [pjata] etc. (1951:118, see also Hock 1985), while Hall argues for coalescence, such that j-pata becomes [p $p^{j}$ ata] (2000:727). From the perspective of our prosodic account, palatalization in Zoque is neither metathesis (two segments) nor coalescence (one): once palatal glides and consonants are syllabified into a single onset, they are phonologically unordered and their phonetic timing will be the same as with underived palatalization, i.e. $\left[p^{j}\right]$ rather than $\left[{ }^{j} p\right] .{ }^{24}$

Finally, Isthmus Mixe (Dieterman 2008) has a prefix $j$ - that causes palatalization of the first consonant in the stem (64a), reminiscent of Zoque. Moreover, the language has several different $-j$ suffixes (a deverbalizer, a clause-final marker, and a transitive marker) that cause palatalization of the stem-final consonant (64b). While the language generally forbids word-initial clusters, there is one (morphologically complex) exception, showing that onset clusters are palatalized throughout (64c); and the same can be seen for coda clusters under suffixation of $-\mathrm{j}(64 \mathrm{~d})$ :

24 Archi (Kibrik 1994: 305) presents a similar case of apparent metathesis, whereby the prefix w- switches

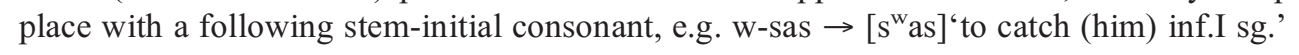


(64) Palatalization in Isthmus Mixe (Dieterman 2008: 33, 39)
a. [pam] 'illness'
[p $\left.p_{\sim}^{\mathrm{j}} \underset{\sim}{\mathrm{am}}\right]$ 'her illness'
b. [turt] 'to lay eggs'
[turt $\left.\mathrm{t}^{\mathrm{j}}\right]$ 'egg'
c. $\left[\int^{\mathrm{j}} n^{\mathrm{j}}{ }_{\text {iwwij }}\right]$ '(he) knows me'
(from /j-S-niwijij-j/)
d. $\quad\left[\mathrm{mja}^{\mathrm{h}}{ }^{\mathrm{n}} \underset{\sim}{\mathrm{amna}} \mathrm{C}^{\mathrm{h}} \mathrm{p}^{\mathrm{j}}\right]^{\mathrm{j}}$ 'you heal'
(from $/ \mathrm{m}-\mathrm{ja}{ }^{\mathrm{h}}-$ pam- $\mathrm{\sim}^{\mathrm{h}}-\mathrm{S}-\mathrm{p}-\mathrm{j} /$ )

Neither metathesis nor coalescence seem to be the correct view of palatalization in Isthmus Mixe. As for metathesis, $\mathrm{j}$ does not really switch places with consonants in clusters; as for coalescence, it is hard to see to which consonant of a cluster $\mathrm{j}$ will actually merge with. Rather, palatality is associated with stem-inital onsets (and stem-final codas) as a whole, just as our prosodic account predicts. Dieterman comes to a very similar conclusion:

Describing secondary palatalization as an autosegmental feature obviates the need for a set of palatalized consonants on the phonemic level and does not complicate the linear consonant-vowel structures of the syllable. The phonetic manifestation of the morpheme is clearly revealed by the autosegmental approach. (Dieterman 2008: 49)

\section{Implications: from segments to seglets}

In classical phonemic theory, ordinary onsets like $[M]$ or $\left[\mathrm{p}^{\mathrm{hj}}\right]$ allow for rather different phonological analyses: $[M]$ could be a voiceless labiovelar glide /w/, but also a labiovelarized aitch $/ \mathrm{h}^{\mathrm{w}} /$, or a cluster $/ \mathrm{hw} /$ or $/ \mathrm{wh} / ;$; $\left[\mathrm{p}^{\mathrm{hj}}\right]$ could be a palatalized, aspirated stop $/ \mathrm{p}^{\mathrm{hj}} /$, an aspirated stop followed by a glide $/ \mathrm{p}^{\mathrm{h}} \mathrm{j} /$, a stop with a palatalized aitch $/ \mathrm{ph}^{\mathrm{j}} /$, a palatalized stop with a plain aitch $/ \mathrm{p}^{\mathrm{j}} \mathrm{h} /$, or a triconsonantal cluster $/ \mathrm{phj} /$. The number of possible analyses increases with every consonant added to the onset: [ $\left.\mathrm{p}_{\mathrm{o}}^{\mathrm{j}}\right]^{\mathrm{j}}$, for instance, could be $/ \mathrm{p}^{\mathrm{hj}} \mathrm{j}^{\mathrm{j}} /$, $/ \mathrm{p}_{\mathrm{o}}^{\mathrm{j}} \mathrm{j}^{\mathrm{j}} /$, /pjhlj/, and so on. And so we find in the literature debates like the following on Chilcotin:

Phonetically, it is difficult, if not impossible, to determine whether this segment is a labialized glottal stop $\left[\mathrm{P}^{\mathrm{w}}\right]$ or a glottalized labiovelar sonorant [w']. Krauss and Leer (1998:135) raise the same question with respect to the Proto-Athapaskan-Eyak consonant to which the above Chilcotin segment corresponds. (Cook 1983: fn 5)

Feature theory does away with some of these problems. For most models at least, there is no way to distinguish things like $/ \mathrm{T}^{\mathrm{w}} /$ and $/ \mathrm{w} /$. Both consist of a single root node heading a laryngeal feature [constricted] and vocalic features [round, back], with no indication as to which feature class is superior. Bottlebrush models (65) do an admirable job in this respect, refusing to model things differently that don't contrast in natural languages. 
(65) Bottlebrush margins

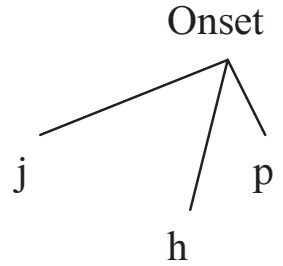

$\left[p h j, p^{h j},{ }^{h} p^{j}, \ldots\right]$

Linguists sometimes argue from the perspective of phonemic economy, phonological processes, historical evidence, and the like in order to advance one or the other phonological analysis: $/ \mathrm{p}^{\mathrm{hj}} /, / \mathrm{p}^{\mathrm{h}} \mathrm{j} /, / \mathrm{ph}^{\mathrm{j}} /, / \mathrm{p}^{\mathrm{j}} \mathrm{h} /$, or $/ \mathrm{phj} /$, but more often than not, arguments from different areas point to different solutions.

If our proposal in (1) is correct, $/ \mathrm{p}^{\mathrm{hj}} /, / \mathrm{p}^{\mathrm{h}} \mathrm{j} /, / \mathrm{ph}^{\mathrm{j}} /, / \mathrm{p}^{\mathrm{j}} \mathrm{h} /$, and $/ \mathrm{phj} /$ are all phonologically equivalent, and the issue is a non-starter. Until we find languages that contrast such things, or treat them differently in phonoloical processes, there is no reason to entertain them seriously as distinct phonological entities. The fact that the contrastive secondary articulations for a simplex onset are the same as those for a complex CC or CCC onset strongly suggests that it is syllable margins that license laryngeal and vocalic secondary articulations rather than segments. The universal patterns in (2)-(4) argue for the same point: it is palatality in an onset that matters in phonology, not a palatal segment vs. a palatalized segment, or a cluster $\mathrm{Cj}$ vs. a segment $\mathrm{C}^{\mathrm{j}}$.

Not everything that can be written in IPA contrasts in natural languages. The segmental nature of the alphabet we use and the theories of phonological organization mustered to support that alphabet have driven a wedge between how we conceive of sounds and how they are actually deployed in language. Just as voicing, aspiration, and glottalization are better modeled as features of syllable margins than as features of individual segments (Kehrein \& Golston 2004), labialization, palatalization, and velarization seem to be better modeled as features of syllable margins than as features of segments. 


\section{References}

Akinlabi, A. (1996). Featural Affixation. Journal of Linguistics 32, pp. 239-289.

Ambrazas, V. (1997) (ed.). Lithuanian Grammar. Lithuania: baltos lankos.

Asu, E. L. and Teras, P. (2009). Estonian. Journal of the International Phonetic Association 39, pp. 367-372.

Barker, M. A. R. (1964). Klamath Grammar. Berkeley/Los Angeles: University of California Press.

Barry, M. (1992). Palatalization, assimilation, and gestural weakening, Speech Communication, 11, pp. 393-400.

Bender, Byron W. 1968. Marshallese phonology. Oceanic Linguistics 7, pp.16-35.

Bhaskararao, P., Hassan, S., Naikoo, I. A., Ganai, P. A., Wani, N. H., and Ahmad, T. (2009). A phonetic study of Kashmiri palatalization. In M. Minegishi et al (eds.). Field Research, Corpus Linguistics and Linguistic Informatics. [Working Papers in Corpusbased Linguistics and Language Education - No.3]. Tokyo: Tokyo University of Foreign Studies, pp. 1-17.

Bird, S. (1999). Dschang syllable structure. In Harry Van Der Hulst and Nancy A. Ritter (eds.), The Syllable: Views and Facts. Berlin: Mouton de Gruyter, pp. 447-476.

Catford, J. C. (1972). Labialization in Caucasian languages, with special reference to Abkhaz. Proceedings of the 7th International Congress of Phonetic Sciences. The Hague, Paris.

Catford, J. C. (1977). Mountain of tongues: the languages of the Caucasus. Annual Review of Anthropology 6, pp. 283-314.

Chew, P. A. (2003). A Computational Phonology of Russian. Parkland Florida: Dissertation.Com.

Chirikba, V. A. (1996). Common West Caucasian. The Reconstruction of its Phonological System and Parts of its Lexicon and Morphology. Leiden: Research School CNWS. [CNWS Publications vol. 48.]

Choi, J. D. (1992). Phonetic underspecification and target interpolation: An acoustic study of Marshallese vowel allophony. UCLA Working Papers in Phonetics (No. 82).

Clark, M. M. (1990). The tonal system of Igbo. Dordrecht: Foris.

Clements, G. N. (2001). Representational economy in constraint-based phonology. In T. A. Hall (ed.) Distinctive feature theory. Berlin \& New York: Mouton de Gruyter, pp. 71146.

Clements, G. N. (2003). Feature economy in sound systems. Phonology 20, pp. 287-333.

Clements, G. N. and Hume, E. (1995). The internal organization of speech sounds. In J. Goldsmith (ed.), Handbook of Phonology. Oxford: Blackwell, pp. 245-306. 
Cook, E.-D. (1983). Chilcotin flattening. Canadian Journal of Linguistics, 28 (2), pp. 123132.

De Jong, K. and Obeng, S. G. (2000). Labio-palatalization in Twi: contrastive, quantal, and organizational factors producing an uncommon sound. Language 76, pp. 682-703.

Dieterman, J. I. (2008). Secondary Palatalization in Isthmus Mixe: A Phonetic and Phonological Account. SIL e-Books 11. SIL International.

Duanmu, S. (1999). Syllable structure in Chinese. In H. van der Hulst, and N. Ritter (eds.), The Syllable: Views and Facts. Studies in Generative Grammar 45. Berlin: Mouton de Gruyter, pp. 477-499.

Duanmu, S. (2000). The Phonology of Standard Chinese. Oxford: Oxford University Press.

Dumézil, G. (1965). Documents anatoliens sur les langues et les traditions du Caucase, III: Nouvelles études oubykhs. Paris: Librairie A. Maisonneuve.

Firth, J. R. (1948). Sounds and prosodies. Transactions of the Philological Society, pp. 127152.

Firth, J. R. (1957). Papers in Linguistics. London: Oxford University Press.

Goldsmith, J. (1990). Autosegmental and Metrical Phonology. Oxford \& Cambridge, MA: Basil Blackwell.

Golston, C., and Kehrein, W. (1998). Mazatec onsets and nuclei. International Journal of American Linguistics 64.4, pp. 311-337.

Gordon, M. (2001). Laryngeal timing and correspondence in Hupa. UCLA Working Papers in Phonology 5, 1-70.

Hall, T. A. (1997). The phonology of coronals. Amsterdam: John Benjamins.

Hall, T. A. (2000). Typological generalizations concerning secondary palatalization. Lingua 110, pp. $1-25$.

Halle, M. (1959). The sound pattern of Russian. The Hague: Mouton.

Halle, M., Vaux, B., and Wolfe, A. (2000). On feature spreading and the representation of place of articulation. Linguistic Inquiry 31, pp. 387-444.

Harris, Z. (1944). Simultaneous components in phonology. Language 20, pp. 181-205.

Haudricourt, A.-G. 1967. La langue lakkia. Bulletin de la Société de Linguistique de Paris 62, pp. $165-182$.

Henderson, E. J. A. (1970). Acoustic features of certain consonants and consonant clusters in Kabardian. Bulletin of the School of Oriental and African Studies, University of London, 33, pp. 92-106.

Hock, H. H. (1985). Regular metathesis. Linguistics 23, pp. 529-546.

Hockett, C. F. (1955). A Manual of Phonology. [Indiana University Publications in Anthropology and Linguistics; Memoir 11 of IJAL.] Baltimore: Waverly Press.

Hoffmann, C. (1963). A Grammar of the Margi Language. Oxford University Press for International African Institute, London. 
Houtzagers, P. (2003): Russische Grammatica. Bussum: Coutinho.

Howard, D. E. (2010). Adzera organized phonology data. Morobe Province, Papua New Guinea. Ms., http://www.sil.org/pacific/png/abstract.asp?id=52507.

Hyman, L. (1970). How concrete is phonology? Language 46.1, pp. 58-76.

Jones, D. and Ward, D. (1969). The Phonetics of Russian. Cambridge: Cambridge University Press.

Kaye, J. and Lowenstamm, J. (1984). De la syllabicité. In F. Dell, D. Hirst, and J. R. Vergnaud (eds.), Forme sonore du langage. Paris: Hermann.

Kanu, S. M. and Tucker, B. V. (2010). Temne. Journal of the International Phonetic Association, 40.02, pp. 247-253.

Kehrein, W. and Golston, C. (2004). A prosodic theory of laryngeal contrasts. Phonology 21, pp. 325-257.

Kibrik, A. E. (1994). Archi. In R. Smeets (ed.), The Indigenous Languages of the Caucasus, Vol. 4. Delmar, NY: Caravan Books, pp. 297-365.

Kochetov, A. (1999). Phonotactic constraints on the distribution of palatalized consonants. Toronto Working Papers in Linguistics 17, pp. 171-212.

Kochetov, A. (2002). Production, perception, and emergent phonotactic patterns: A case of contrastive palatalization. New York, London: Routledge.

Kochetov, A. (2005). [-back] assimilation in Balto-Slavic and the nature of phonotactic constraints. In M.-O. Junker, M. McGinnis, and Y. Roberge (eds), Proceedings of the 2004 Canadian Linguistics Association Annual Conference. http://eastcree.org/mojunker/ACL-CLA/pdf/Kochetov-CLA-2004.pdf. 10 pages.

Kochetov, A. (2008). Perception of gestural overlap and self-organizing phonological contrasts. In Peter Avery, Elan Dresher, \& Keren Rice (eds.), Contrast in phonology: Perception and acquisition. New York: Mouton de Gruyter, pp. 173-196.

Kuipers, A. N. (1960). Phoneme and morpheme in Kabardian. Janua Linguarum Series Minor 8. 'S-Gravenhage: Mouton.

Ladefoged, P. (1964). A Phonetic Study of West African Languages. West African Languages and Monographs 1. Cambridge: Cambridge University Press.

Ladefoged, P. (1971). Preliminaries to linguistic phonetics. Chicago: University of Chicaso Press.

Ladefoged, P. and Maddieson, I. (1996). The Sounds of the World's Languages. Oxford: Blackwell.

Ladefoged, P., Ladefoged, J., Turk, A., Hind, K., and Skilton, St. J. (1998). Phonetic structures of Scottish Gaelic. Journnal of the International Phonetic Association 28.1, pp. $1-41$.

Laver, J. (1994). Principles of Phonetics. Cambridge: Cambridge University Press. 
Lehiste, I. 1965. Palatalization in Estonian: some acoustic observations. In V. Kõressaar and A. Rannit (eds.), Estonian poetry and language. Stockholm: Vaba Eesti, pp. 136-162.

Leslau, W. (1958). The verb in Harari: (South Ethiopic). Berkeley: University of California Press.

Maddieson, I. (1984). Patterns of Sounds. Cambridge: Cambridge University Press.

Maddieson, I., and Anderson, V. (1994). Phonetic structures of Iaai. In UCLA Working Papers in Phonetics 87: Fieldwork Studies of Targeted Languages II.

Maddieson, I., and Precoda, K. (1990). Updating UPSID. UCLA Working Papers in Phonetics 74, pp. 104-120.

McCarthy, J. J. 1983. Consonantal morphology in the Chaha verb. Proceedings of the West Coast Conference on Formal Linguistics 2, pp. 176-188.

Mohrlang, R. (1972). Higi phonology. Studies in Nigerian Languages 2. Zaria: Institute of Linguistics and Centre for the Study of Nigerian Languages.

Moldalieva, G. (2012). Interesting cases of palatalization in Russian. Ms, California State University Fresno.

Mudzingwa, C. (2010). Shona morphophonemics: repair strategies in Karanga and Zezuru. University of British Columbia doctoral dissertation.

Ní Chiosáin, M. (1994). Irish palatalization and the representation of place features. Phonology 11, pp. 89-106.

Ní Chiosáin, M. (1999). Syllables and phonotactics in Irish. In H. van der Hulst and N. A. Ritter (eds.), The syllable: Views and facts, Berlin: Mouton de Gruyter, pp. 551-75.

Odden, D., and Odden, M. (1999). Kihehe syllable structure. In H. van der Hulst \& N. Ritter (eds), The syllable: views and facts. Mouton de Gruyter, pp. 417-445.

Padgett, J. (2008). Glides, vowels, and features. Lingua 118.12, pp. 1937-1955.

Paris, C. (1989). West Circassian (Adyghe: Abzakh dialect). In B. G. Hewitt (ed.), The Indigenous Languages of the Caucasus. Volume 2. The North West Caucasian Languages. New York: Caravan, pp. 155-260.

Payne, D. L. (1981). The phonology and morphology of Axininca Campa. Arlington, TX: Summer Institute of Linguistics.

Pike, K. L. and Pike, E. V. (1947). Immediate constituents of Mazatec syllables. International Journal of American Linguistics 13, pp. 78-91.

Sagey, E. (1986). The representation of features and relations in nonlinear phonology. MIT: Doctoral dissertation.

Schuh, R. G. and Yalwa, L. D. (1993). Journal of the International Phonetic Association 23.2 , pp. 77-82.

Skalozub, L. G. (1963). Palatogrammy i rentgenogrammy soglasnykh fonem russkogo literaturnogo iazyka. Kiev: Izdatel'stvo Kievskogo universiteta. 
Steriade, D. (1994). Complex onsets as single segments: the Mazateco pattern. In Jennifer Cole \& Charles Kisseberth (eds.), Perspectives in Phonology. Stanford: CSLI Publications, pp. 203-291.

Stonham, J. (1999). Aspects of Tsishaath Nootka phonetics and phonology. Munich: LINCOM Europa.

Timberlake, A. (2004). A reference grammar of Russian. Cambridge: Cambridge University Press.

Weijer, J. M. van de (2011). Secondary and double articulation. In Marc van Oostendorp, Colin J. Ewen, Elizabeth V. Hume and Keren D. Rice (eds.) The Blackwell Companion to Phonology. London: Wiley-Blackwell, pp. 694-710.

Westerman, D. and Bryan, M. A. (1952). Handbook of African Languages, part II, Languages of West Africa. London: Oxford University Press.

Wonderly, W. L. (1951). Zoque II: phonemes and morphophonemes. International Journal of American Linguistics 17, pp. 105-123.

Yearley, J. (1995). Jer vowels in Russian. In J. N. Beckman, L. W. Dickey, \& S. Urbanczyk (eds.), Papers in optimality theory. Amherst: GLSA, University of Massachusetts). Occasional papers in linguistics 18, pp. 533-571. 